\title{
38. MAGNETOBIOSTRATIGRAPHIC SYNTHESIS OF LEG 123: SITES 765 AND 766 (ARGO ABYSSAL PLAIN AND LOWER EXMOUTH PLATEAU) ${ }^{1}$
}

\author{
Michael A. Kaminski, ${ }^{2}$ Peter O. Baumgartner,${ }^{3}$ Paul R. Bown, ${ }^{4}$ David W. Haig, ${ }^{5}$ Andrew McMinn, ${ }^{6}$ Michael J. Moran, ${ }^{7}$ \\ Jörg Mutterlose, ${ }^{8}$ and James G. Ogg ${ }^{9}$
}

\begin{abstract}
During ODP Leg 123, Sites 765 and 766 were drilled to examine the tectonic evolution, sedimentary history, and paleoceanography of the Argo Abyssal Plain and lower Exmouth Plateau. At each site, the quality of magnetostratigraphic and biostratigraphic records varies because of complicating factors, such as the predominance of turbidites, the presence of condensed horizons, or deposition beneath the CCD.

Based primarily on the presence of nannofossils, the base of the sedimentary section at Site 765 was dated as Tithonian. A complete Cretaceous sequence was recovered at this site, although the sedimentation rate varies markedly through the section. The Cretaceous/Tertiary boundary is represented by a condensed horizon. The condensed Cenozoic sequence at Site 765 extends from the upper Paleocene to the lower Miocene. A dramatic increase in sedimentation rate was observed in the lower Miocene, and a 480-m-thick Neogene section is present. The Neogene section is continuous, except for a minor hiatus in the lower Pliocene.

The base of the sedimentary section at Site 766 is Valanginian, in agreement with the site's position on marine magnetic anomaly M11. Valanginian to Barremian sediments are terrigenous, with variable preservation of microfossils, and younger sediments are pelagic, with abundant well-preserved microfossils. Sedimentation rate is highest in the Lower Cretaceous and decreases continually upsection. Upper Cenozoic sediments are condensed, with several hiatuses.
\end{abstract}

\section{INTRODUCTION}

Leg 123 offered an excellent opportunity for scientists to examine microfossil faunas and floras from the southern margin of the Tethys Ocean and to compare these with the better known faunas and floras of the low latitudes. A major goal of the cruise was to recover a continuously cored microfossil record from the oldest part of the Indian Ocean and to compare these results with the unique record obtained at DSDP Site 261, which was drilled during DSDP Leg 27. Two sites were drilled during Leg 123 (Fig. 1). Site 765 was drilled on what was assumed to be the oldest oceanic crust in the Argo Abyssal Plain. Site 766, at the foot of the Exmouth Plateau, was drilled to investigate the early breakup history of India and northwestern Australia. Here, we summarize the magnetostratigraphic and biostratigraphic results obtained at these two sites.

\section{CHRONOSTRATIGRAPHY}

We established a biostratigraphic and chronostratigraphic framework for use during drilling operations on Leg 123. The chronostratigraphy for the Cenozoic (Figs. 2 and 3) follows the scheme of Berggren et al. (1985a, 1985b), with minor modifica-

\footnotetext{
${ }^{1}$ Gradstein, F. M., Ludden, J. N., et al., 1992. Proc. ODP, Sci. Results, 123: College Station, TX (Ocean Drilling Program).

Department of Geology, University College, London, Gower Street, London WC1E 6BT, U.K., and Department of Paleoceanography, GEOMAR, Wischhofstrasse 1-3, D-2300 Kiel-14, Germany.

${ }^{3}$ Institut de Géologie, BFSH2, 1045 Lausanne, Switzerland.

${ }^{4}$ Department of Geology, University College, London, Gower Street, London WC11E 6BT, U.K.

5 Department of Geology, University of Western Australia, Nedlands 6009, Australia.

${ }_{6}^{6}$ Geological Survey of New South Wales, Kensington 2300 , N.S.W., Australia.

${ }^{7}$ Department of Geology, University of Papua New Guinea, Port Moresby, Papua New Guinea.

${ }^{8}$ Institut für Geologie und Paläontologie, Universität Hannover, Callinstrasse 30,3000 Hannover 1, Germany.

${ }^{9}$ Department of Earth and Atmospheric Sciences, Purdue University, West Lafayette, IN 47907, U.S.A.
}

tions to the stage boundaries and zonal correlation based on new data by Zijderveld et al. (1986) and Aubry et al. (1988). For the Mesozoic (Fig. 4), the chronostratigraphic nomenclature of Kent and Gradstein (1986) was used. Both these scales use high-temperature radiometric dates, rather than low-temperature dates, or a mixture of both. However, all numeric scales are hindered by a lack of direct dates for most chronostratigraphic boundaries. For our purposes, we updated the Mesozoic time scale, using new correlations of Lower Cretaceous stage boundaries with magnetostratigraphy. These correlations are based on Ogg (1984), Ogg and Lowrie (1986), Bralower (1987), and Ogg and Steiner (1988). The following correlations were used (1) the Barremian/Aptian boundary was placed slightly below M0R (119 Ma); (2) the Valanginian/Hauterivian boundary was placed within or near M10R (131.5 Ma); (3) the Berriasian/Valanginian boundary was placed in the middle of M15N (138.5 Ma); and (4) the Tithonian/Berriasian boundary was placed in the middle of M19N (145 Ma).

Although the scientific objectives of Leg 122 on the Exmouth Plateau were planned in conjunction with those of Leg 123, here we must issue a cautionary note to the readers of both scientific volumes. In contrast to standard ODP practice, the shipboard scientific party of Leg 122 used the time scale of Haq et al. (1987). Because the ages of chronostratigraphic boundaries between the two time scales differ by as much as several million years, direct comparisons of geochronology with rates of sedimentary processes are complicated.

\section{BIOSTRATIGRAPHY}

\section{Calcareous Nannofossils}

Cenozoic calcareous nannofossil zonations used during Leg 123 include Gartner (1977) for the Pleistocene and Martini (1971), Okada and Bukry (1980), and Bukry (1981) for the remainder of the Cenozoic. All zonations were reasonably applicable to the eastern Indian Ocean and, where usable, Okada and Bukry's zonation was preferred over Martini's zonation because of its higher resolution. 


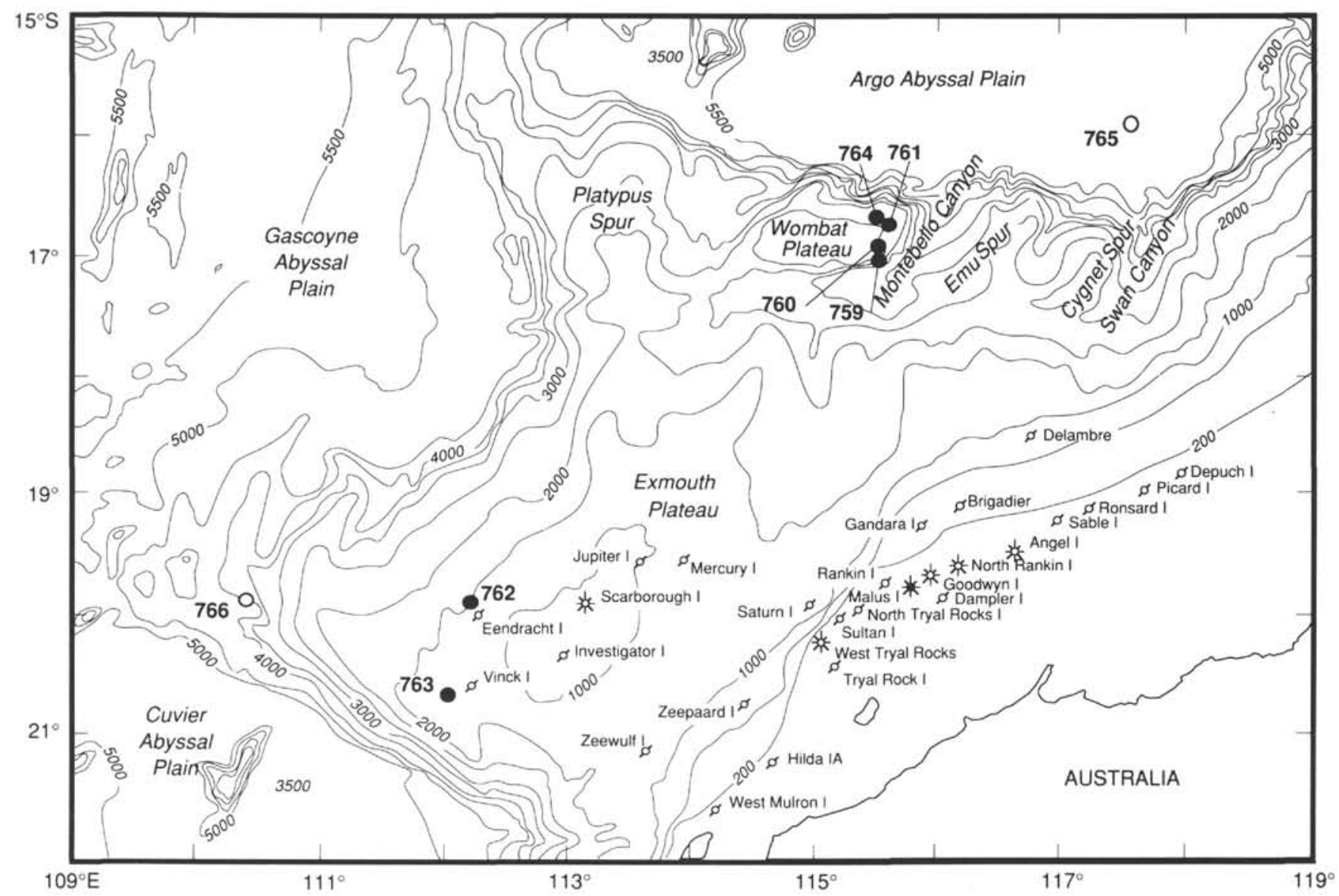

Figure 1. Map showing Leg 123 Sites 765 and 766 off northwestern Australia. Bathymetric contours in meters.

The zonations of Thierstein (1971, 1976), Sissingh (1977), and Roth (1978), as well as unpublished data, were used to correlate Cretaceous strata. The small amount of nannofossil research from Jurassic sequences has thus far precluded the use of a widely accepted zonal scheme. For the Upper Jurassic to Lower Cretaceous interval, data from DSDP Site 261 were used and include those of Proto Decima (1974) and Cooper (1984). Other zonal schemes employed include those of Thierstein (1976), Roth et al. (1983), Bralower (1987), Bown et al. (1988), and Mutterlose (in press).

The mixing of assemblages is less pronounced in the Cretaceous sediments and probably reflects less erosive turbidity currents. The abundance and preservation of nannofossils decline in the Lower Cretaceous part of the section where several barren intervals occur.

Hole $766 \mathrm{~A}$ contains generally abundant Cenozoic and Upper Cretaceous nannofossil assemblages, and the overall preservation is moderate to good. Little evidence of reworking was observed in the assemblages from this hole, indicating normal, pelagic deposition. Lower Cretaceous nannofossils are less abundant and diverse, but were found in a consistently good state of preservation, despite unfavorable lithologies at the base of the hole.

\section{Planktonic Foraminifers}

The tropical zonation of Blow (1969) as amended by Kennett and Srinivasan (1983) was used during Leg 123. The boundary between Zones "N19" and "N20" was taken at the first appearance of Globorotalia crassaformis. The first appearance of Sphaeroidinella dehiscens may be diachronous in the Indian Ocean (Vincent, 1977) and may be unsuitable for marking the boundary between Zones "N18" and "N19." This level is approximately coincident with the first appearance of Globorotalia (Hirsutella) margaritae, as defined by Kennett and Srinivasan (1983), and the extinction of Globorotalia (Globorotalia) plesiotumida. The Nzonation has been used extensively in the Australian Northwest Shelf region (Apthorpe, 1988; Chaproniere, 1981) and elsewhere in the Indian Ocean.

In the Paleogene part of the succession, the tropical zonation of Blow $(1969,1979)$ was applied to the upper Eocene-Oligocene, and Berggren's (1969) zonation was used for the Paleocene to mid-Eocene. A similar zonal scheme was employed for the Wombat Plateau drilled during Leg 122 (Shipboard Scientific Party, 1990) and by McGowran (1977) for DSDP sites in the Indian Ocean.

Cretaceous sediments were zoned using the scheme of Caron (1985) for the Aptian to Maestrichtian. Because many index species are missing from the low-diversity Cretaceous assemblages recovered from this section, most of the zonal assignments are broad. Planktonic assemblages recorded elsewhere from the northwest Australian margin also lack many of the zonal index forms (Belford, 1981; Herb and Schreibnerova, 1977; McGowran, 1977; Wright and Apthorpe, 1976). The scattered Early Cretaceous planktonic foraminifers encountered during Leg 123 were zoned following Stam (1986), but species in his zonal scheme have not yet been documented from the Indian Ocean.

At Site 765 , the application of planktonic foraminiferal biostratigraphy in the Cenozoic part of the sequence was constrained by the allochthonous nature of the sediments and the large amount of reworking. Analysis of planktonic foraminiferal assemblages was performed mainly on shipboard core-catcher samples. Middle 
MAGNETOBIOSTRATIGRAPHIC SYNTHESIS, LEG 123

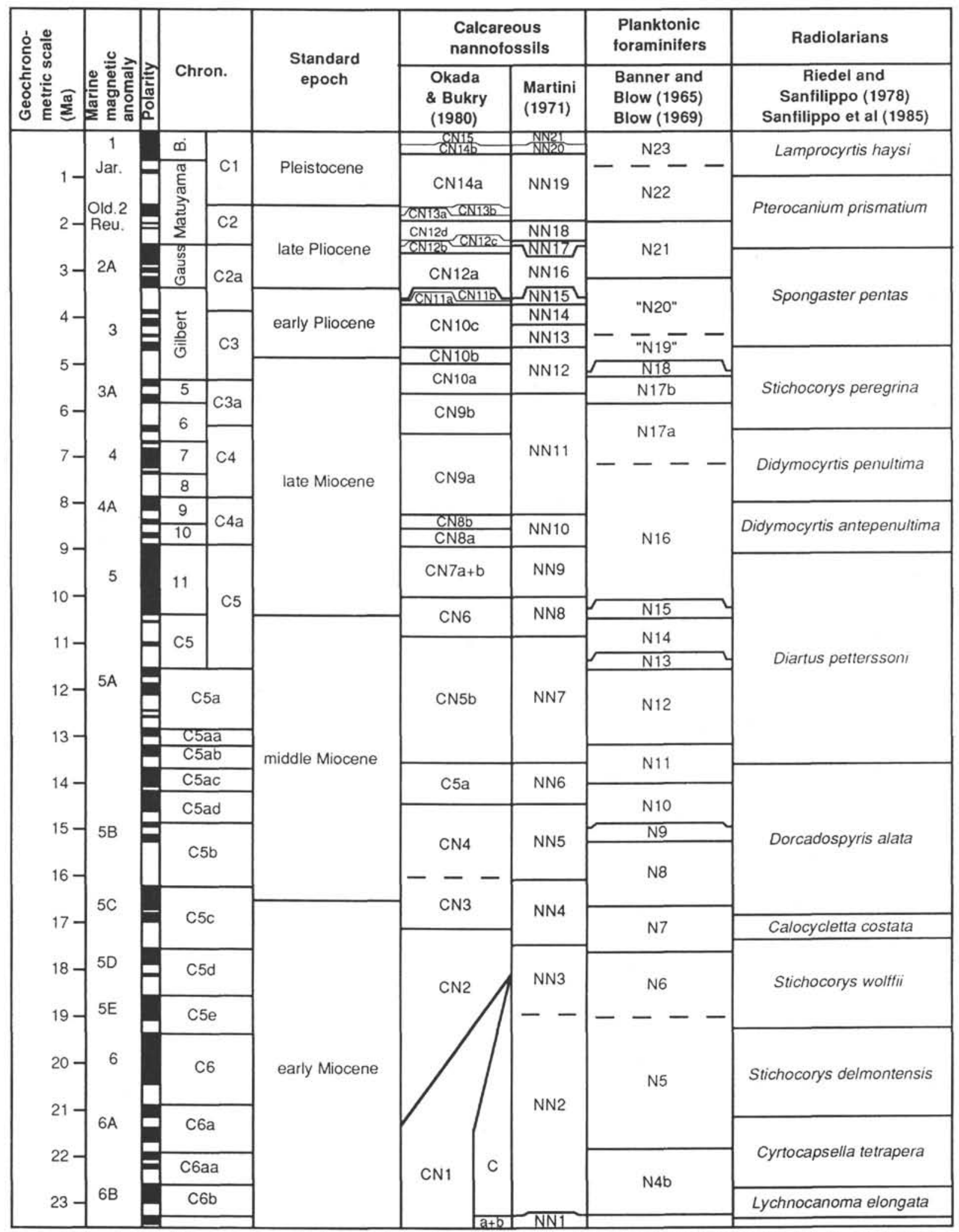

Figure 2. Correlation of Neogene chronostratigraphy, biostratigraphy, and magnetostratigraphy used during Leg 123. The revised age of the Miocene/Pliocene boundary is after Zijderveld et al. (1986). Correlation of Pliocene/Pleistocene radiolarian zones to magnetostratigraphy follows Sanfilippo et al. (1985), correlation of Miocene zones follows Berggren et al. (1985b). Magnetic chron terminology follows that adopted by Leg 108 (Ruddiman, Sarnthein, et al., 1988). Interpolated ages of magnetic polarity reversals and planktonic foraminiferal/nannofossil datums used to define zones are after Berggren et al. (1985b). Planktonic foraminiferal "N" zonation is modified slightly after Kennett and Srinivasan (1983). Zone N17 was subdivided into two parts using the FO of Pulleniatina primalis; Zone N4B was subdivided based on the FO of Globoquadrina dehiscens; the base of N13 is defined by the LO of the G. fohsi lineage, and the base of $\mathrm{N} 20$ is defined here as the $\mathrm{FO}$ of $G$. crassaformis s.l. at $4.3 \mathrm{Ma}$. 


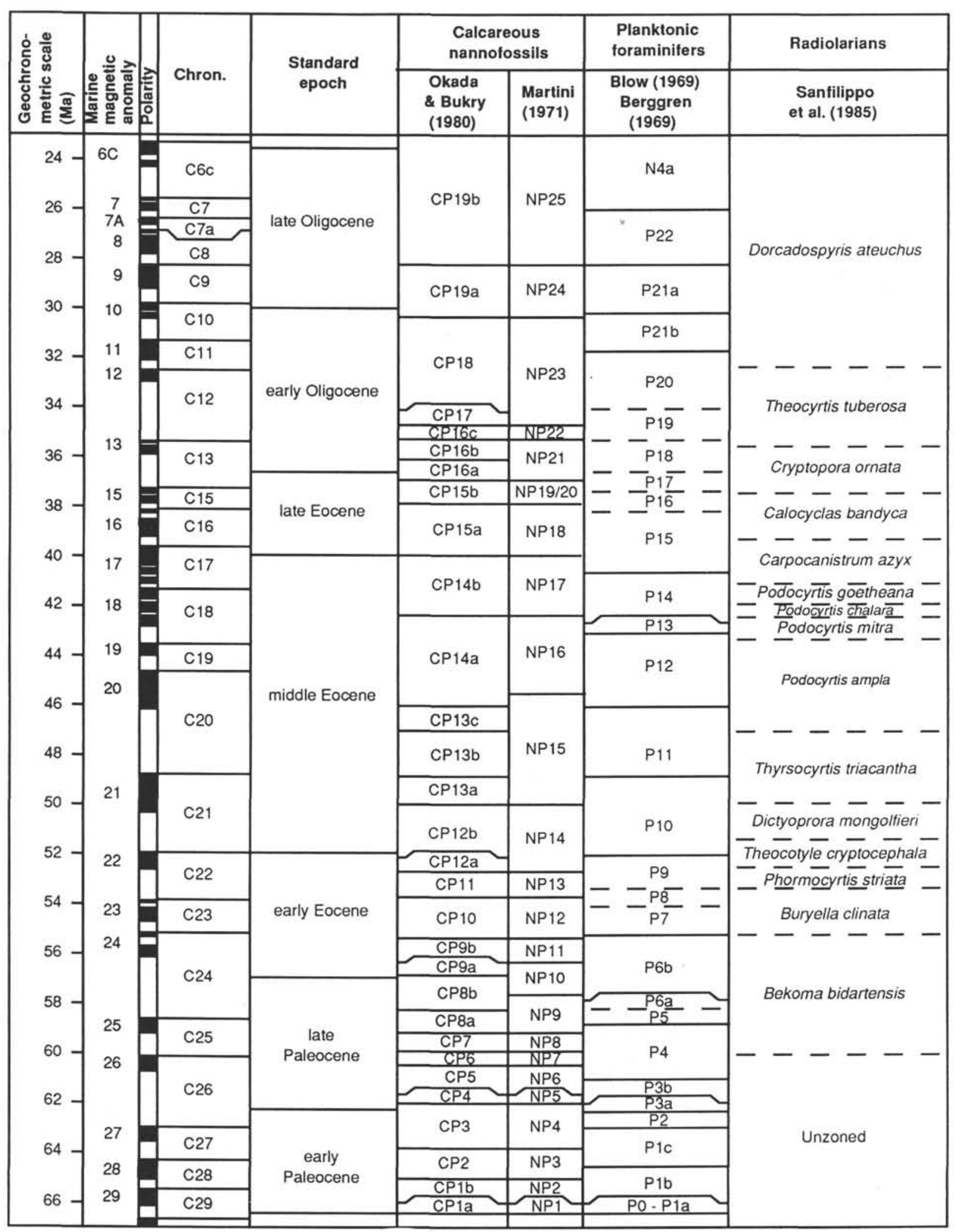

Figure 3. Correlation of Paleogene chronostratigraphy, biostratigraphy, and magnetostratigraphy used during Leg 123. The revised age of the Paleocene/Eocene boundary is after Aubry et al. (1988). Correlation of radiolarian zones (Sanfilippo et al., 1985) follows correlation of nannofossil zones of Berggren et al. (1985a). 


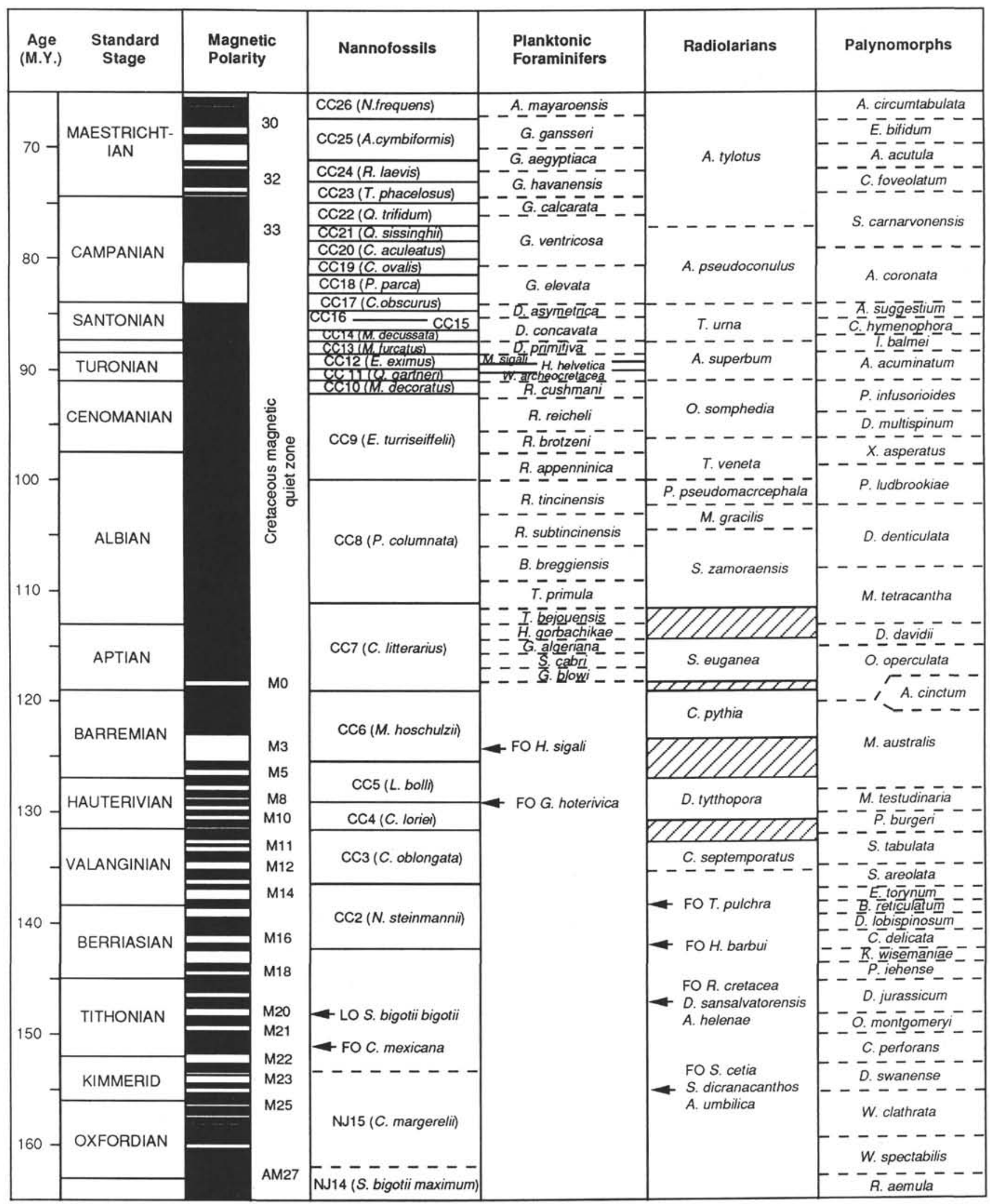

Figure 4. Correlation of Cretaceous chronostratigraphy, biostratigraphy, and magnetostratigraphy used during Leg 123. The revised ages of the Lower Cretaceous stage boundaries follow Ogg and Steiner (1988). Nannofossil zonation follows that of Sissingh (1977); planktonic foraminiferal zonation follows Caron (1985); radiolarian zonation follows Baumgartner (1984). Palynomorph zonation for northwest Australia is adopted from Helby et al. (1987) and McMinn (1988b). Dashed lines indicate second-order correlations to magnetostratigraphy. 
Miocene assemblages were especially poorly preserved, with specimens often having thick overgrowths of sparry calcite. $\mathrm{Pa}$ leogene and Upper Cretaceous assemblages display moderate to good preservation, although reworking was also observed.

At Site 766, planktonic foraminifers are abundant and well preserved in the upper part of the Cenozoic, but dissolution increases downhole. Paleogene and Cretaceous assemblages are poorly preserved, with only rare, small-sized planktonics. Cenomanian and Turonian assemblages contain abundant but poorly preserved forms.

\section{Benthic Foraminifers}

The Cenozoic biostratigraphy of calcareous benthic foraminifers recovered during Leg 123 was compared with the biostratigraphic ranges of Tjalsma and Lohmann (1983) and Van Morkhoven et al. (1986). These biostratigraphic schemes were applicable at Site 766, but because of the location of Site 765 beneath the $\mathrm{CCD}$, benthic foraminifers were recovered mainly from turbidites.

The Upper Cretaceous zeolitic clays at DSDP Site 261 on the Argo Abyssal Plain contain a distinct assemblage of small, agglutinated foraminifers (Krasheninnikov, 1974). Leg 123 biostratigraphy of these taxa, some of which may be unique to the abyssal realm, was based on the zonation of Geroch and Nowak (1984). This zonation is based on similar assemblages from the Carpathian flysch basins and has been used successfully for Upper Cretaceous abyssal red clay sediments from DSDP Site 603 and ODP Site 641 in the North Atlantic (Moullade et al., 1988; Kuhnt and Kaminski, 1989). The taxonomy and biostratigraphy of Upper Cretaceous calcareous benthic foraminifers recovered during Leg 123 follow Sliter (1980) and Dailey (1983).

Lower Cretaceous deep-water benthic foraminifers were dated using the taxonomy and biostratigraphy of Bartenstein and Brand (1951), Luterbacher (1972), Maync (1973), Bartenstein (1974), Kuznetsova (1974), Kuznetsova and Seibold (1977), Gradstein (1978, 1983, 1986), Sliter (1980), Moullade (1984), and Riegraf and Luterbacher (1989). However, because no formal zonation based on cosmopolitan deep-water benthic foraminifers has been proposed for the Lower Cretaceous, we report the first and last occurrences of selected taxa for comparative purposes only.

At Site 765, the abundance and diversity of Cenozoic benthic foraminifers parallel those of planktonic foraminifers. Assemblages from the Neogene turbidites are size-sorted with variable preservation, whereas Paleogene and Upper Cretaceous assemblages are better preserved. One sample was found to contain an Upper Cretaceous abyssal agglutinated assemblage. The Cenomanian section is represented in an agglutinated facies. Samples from the Albian and Aptian are barren. However, the diversity of agglutinated forms recovered in the Neocomian section at Site 765 is much higher than previously recorded from any DSDP/ ODP site, which underscores the need for more taxonomic and biostratigraphic research among this group of abyssal organisms.

Benthic assemblages from Site 766 are well preserved and composed of cosmopolitan, deep-water calcareous species. Benthic foraminifers are abundant in the Cenozoic and Upper Cretaceous, but decline in abundance in the Lower Cretaceous. Preservation in the sandy sediments at the base of the hole is poor.

\section{Radiolarians}

Cenozoic radiolarian assemblages were assigned to biozones initially proposed by Riedel and Sanfilippo (1978) and later reviewed by Sanfilippo et al. (1985). The late Neogene correlation of radiolarian datums to magnetostratigraphy by Casey and Reynolds (1980) proved useful.

At present, no standard radiolarian zonation is available for the Cretaceous. Ages were based on an integration of radiolarian ranges proposed by Sanfilippo and Riedel (1985), Schaaf (1981, 1985), Pessagno (1977), and Aita (1987). The lowermost Cretaceous was zoned after Baumgartner $(1984,1987)$. At the Leg 123 sites, the use of published radiolarian zonations proved difficult because of the scarcity of low-latitude (Tethyan) species known from other oceans. Therefore, we report the first and last occurrences of selected taxa for comparative purposes only.

\section{Palynomorphs}

No Southern Hemisphere or tropical Cenozoic dinoflagellate zonation is widely accepted, but one of the more applicable ones is that of Williams (1977). Hansen (1977) produced a detailed Maestrichtian/Danian boundary zonation that can be applied with success to the northwest Australian margin (McMinn, 1988a). The zonation of Helby et al. (1987) was used for the Jurassic to Lower Cretaceous dinoflagellate assemblages. The most applicable Upper Cretaceous zonation is that of McMinn (1988b), which was developed based on material from the northwest Australian margin.

\section{SITE 765}

Site 765 is located at $15^{\circ} 58.541^{\prime} \mathrm{S}, 117^{\circ} 34.495^{\prime} \mathrm{E}$ at a water depth of $5723 \mathrm{~m}$ about $15 \mathrm{~km}$ seaward of the geophysical continent/ocean boundary that separates Australia from the Argo Abyssal Plain. The site is located on marine magnetic anomaly M26, which is of late Oxfordian age. Four holes were drilled at the site. Hole 765A did not recover the mud line and was abandoned after recovering one core. Hole $765 \mathrm{~B}$, drilled using the advanced piston corer and extended core barrel, recovered $395.6 \mathrm{~m}$ of sediment in 41 cores, with an average recovery of $68 \%$. Hole $765 \mathrm{C}$ was washed down to a sub-bottom depth of $350.2 \mathrm{~m}$, then cored using the rotary core barrel to $935.6 \mathrm{mbsf}$. From Hole $765 \mathrm{C}, 613.7 \mathrm{~m}$ of section was recovered (including $30 \mathrm{~m}$ of basaltic basement) in 65 cores, with an average recovery of $60 \%$. Hole $765 \mathrm{D}$ was washed to basement to drill basalt; no sediments were recovered.

\section{Hole 765B}

Site 765 is presumed to have been situated for most, if not all, of its history beneath the CCD. Therefore, the occurrence of calcareous microfossils is directly related to the presence of graded carbonate turbidites derived from the shelf or slope. Radiolarians also occur in the upper nine cores of the hole. Palynomorphs occur in scattered samples, but the lack of a standard Cenozoic zonation limits their usefulness for age determination. Nannofossils and planktonic foraminifers are always present in the turbidites and make up a significant part of the sediment. Preservation varies from poor in the coarse-grained basal units of the turbidites to good toward the top of the graded units. Planktonic foraminifers are best represented in the turbidite sands. These coarse sands contain sorted assemblages of large-size specimens, whereas the finer parts of graded beds contain mainly juvenile forms that were difficult to classify. Intervals barren of carbonate overlie the graded units; these represent the autochthonous abyssal sediments. Some of these sediments contain radiolarians. Throughout the hole, nannofossil assemblages commonly exhibit significant degrees of reworking, which limits the use of last occurrence datums.

The natural remanent magnetization (NRM) intensity of the calcareous turbidites is generally weak $(0.1$ to $1 \mathrm{~mA} / \mathrm{m})$, but the intercalated pelagic sediments have intensities greater than 1 $\mathrm{mA} / \mathrm{m}$. Alternating field (AF) demagnetization of the cores yielded stable directions of demagnetization, enabling identification of a polarity pattern. Polarity chronozones were assigned according to the nannofossil and foraminifer biostratigraphy and the magnetic-polarity time scale.

The chronostratigraphy of Hole $765 \mathrm{~B}$ is constrained by a total of 17 biostratigraphic events (Table 1). These consist mainly of 
Table 1. Chronostratigraphy of Hole 765B, showing 17 biostratigraphic events.

\begin{tabular}{|c|c|c|c|c|}
\hline & Datum/zone & Interval & $\begin{array}{l}\text { Age } \\
\text { (Ma) }\end{array}$ & Reference \\
\hline R & C. tuberosa Zone & $1 \mathrm{H}$, top to $2 \mathrm{H}-\mathrm{CC}$ & $0-0.6$ & Sanfilippo et al., 1985 \\
\hline R & A. ypsilon Zone & $2 \mathrm{H}-\mathrm{CC}$ to $5 \mathrm{H}-\mathrm{CC}$ & $0.6-1.0$ & Sanfilippo et al., 1985 \\
\hline $\mathbf{R}$ & A. angulae Zone & $5 \mathrm{H}-\mathrm{CC}$ to $9 \mathrm{H}-\mathrm{CC}$ & $1.0-1.6$ & Sanfilippo et al., 1985 \\
\hline $\mathrm{F}$ & LO G. fistulosus & $2 \mathrm{H}-\mathrm{CC}$ to $3 \mathrm{H}-\mathrm{CC}$ & 1.6 & Berggren et al., 1985 \\
\hline F & LO G. extremus & $3 \mathrm{H}-\mathrm{CC}$ to $4 \mathrm{H}-\mathrm{CC}$ & 1.8 & Berggren et al., 1985 \\
\hline $\mathrm{N}$ & LO D. brouweri & $9 \mathrm{H}-\mathrm{CC}$ to $10 \mathrm{H}-\mathrm{CC}$ & 1.9 & Berggren et al., 1985 \\
\hline $\mathrm{F}$ & FO G. truncatulinoides & $10 \mathrm{H}-\mathrm{CC}$ to $11 \mathrm{H}-\mathrm{CC}$ & 1.9 & Berggren et al., 1985 \\
\hline F & FO G. toseaensis & $13 \mathrm{H}-\mathrm{CC}$ to $14 \mathrm{H}-\mathrm{CC}$ & 3.1 & Berggren et al., 1985 \\
\hline $\mathrm{N}$ & FO P. lacunosa & $14 \mathrm{H}-\mathrm{CC}$ to $15 \mathrm{H}-\mathrm{CC}$ & 3.4 & Berggren et al., 1985 \\
\hline $\mathbf{N}$ & LO $S$. abies and $S$, neoabies & $14 \mathrm{H}-\mathrm{CC}$ to $15 \mathrm{H}-\mathrm{CC}$ & 3.47 & Berggren et al., 1985 \\
\hline $\mathrm{N}$ & LO R. pseudoumbilicata & $14 \mathrm{H}-\mathrm{CC}$ to $15 \mathrm{H}-\mathrm{CC}$ & 3.5 & Berggren et al., 1985 \\
\hline F & S/D coiling $P$ ulleniatina & $15 \mathrm{H}-\mathrm{CC}$ to $16 \mathrm{H}-\mathrm{CC}$ & 3.8 & Berggren et al., 1985 \\
\hline $\mathrm{N}$ & LO D. quinqueramus & $17 \mathrm{H}-\mathrm{CC}$ to $18 \mathrm{H}, \mathrm{CC}$ & 5.6 & Berggren et al., 1985 \\
\hline $\mathrm{N}$ & FO N. quinqueramus & $28 \mathrm{X}-\mathrm{CC}$ to $29 \mathrm{X}-\mathrm{CC}$ & 8.2 & Berggren et al., 1985 \\
\hline $\mathrm{N}$ & FO C. calyculus & $35 \mathrm{X}-\mathrm{CC}$ to $36 \mathrm{X}-\mathrm{CC}$ & 10 & Berggren et al., 1985 \\
\hline M & Brunhes/Matuyama & $5 \mathrm{H}-5,35$ & 0.73 & Berggren et al., 1985 \\
\hline M & Top Jaramillo & Top $8 \mathrm{H}$ & 0.91 & Berggren et al., 1985 \\
\hline M & Bottom Jaramillo & Bottom $8 \mathrm{H}$ & 0.93 & Berggren et al., 1985 \\
\hline M & Bottom Olduvai & Bottom $10 \mathrm{H}$ & 1.68 & Berggren et al., 1985 \\
\hline
\end{tabular}

nannofossils and planktonic foraminifers, with radiolarians also contributing to the Pleistocene biozonation. Additional magnetostratigraphic events contribute to the placement of stage boundaries, particularly in the upper part of the hole. A magnetobiostratigraphic summary of Hole 765B is presented in Figure 5.

Chronostratigraphic resolution within the Pleistocene in Hole $765 \mathrm{~B}$ is excellent, with radiolarians and magnetostratigraphy yielding the best results. Cores $123-765 \mathrm{~B}-1 \mathrm{H}$ and $123-765 \mathrm{~B}-2 \mathrm{H}$ were assigned to the Buccinosphaera invaginata Zone or the Collosphaera tuberosa Zone (Sanfilippo et al., 1985), indicating an age younger than $400,000 \mathrm{yr}$. Cores $123-765 \mathrm{~B}-3 \mathrm{H}$ to $123-$ $765 \mathrm{~B}-8 \mathrm{H}$ were assigned to the Amphirhopalum ypsilon Zone, indicating an age younger than 1.0 Ma. The Brunhes/Matuyama boundary $(0.73 \mathrm{Ma})$ is located $35 \mathrm{~cm}$ below the top of Section 123-765B-5H-5. The normal-polarity zone (recognized from Core $123-765 \mathrm{~B}-8 \mathrm{H}$ to the bottom of Core $123-765 \mathrm{~B}-9 \mathrm{H})$ may be a greatly thickened Jaramillo $(0.91-0.98 \mathrm{Ma})$.

The Pliocene/Pleistocene boundary (1.6 Ma) was placed within Core 123-765B-10H, based on biostratigraphy and magnetics. Radiolarians belonging to the Anthocyrtis angulare Zone $(<1.6 \mathrm{Ma})$ occur in Sample 123-765B-9H-CC, and the FAD of Globorotalia truncatulinoides (1.9 Ma) is found in Sample 123 . $765 \mathrm{~B}-10 \mathrm{H}-\mathrm{CC}$. Therefore, the normal-polarity zone located from the bottom of Core 123-765B-9H to Core 123-765B-10H may be Chron $\mathrm{C} 2 \mathrm{n}$ (Olduvai) (1.66-1.88 Ma), and the reversed-polarity zone from the bottom of Core $123-765 \mathrm{~B}-10 \mathrm{H}$ to $-11 \mathrm{H}$ may be identified as Chron C2r. Samples 123-765B-11H-CC through -14-CC were placed in nannofossil Zone CN12 (Discoaster brouweri Zone) based on the presence of abundant Pseudoemiliania lacunosa and the absence of Gephyrocapsa oceanica. This assemblage suggests a late Pliocene age. Below the upper disturbed interval in Core 123-765B-11H, Cores 123-765B-12H through the upper third of Core $123-765 \mathrm{~B}-17 \mathrm{H}$ display predominantly normal polarity, with reversed polarity in the lower portion of Core $123-765 \mathrm{~B}-13 \mathrm{H}$ and $-15 \mathrm{H}$. The late Pliocene age of this predominantly normal-polarity interval implies a correlation to polarity Chron C2An ("Gauss"), with the two reversed-polarity zones assigned to the two reversed-polarity subchrons within Chron C2An. The underlying reversed-polarity zone comprising the lower two-thirds of Core $17 \mathrm{R}$ is assigned to Chron $\mathrm{C} 2 \mathrm{Ar}$ of earliest late Pliocene age.

The Miocene/Pliocene boundary in Hole 765B is represented by a hiatus or significantly condensed section within Core 123765B-18H. Sample 123-765B-17H-CC belongs in nannofossil Zone CN11 (3.4-3.7 Ma), but below this sample, the upper Mio- cene to lower Pliocene nannofossil Zones CN10a-10c, planktonic foraminifer Zone N19, and uppermost Miocene Zone N18 were not identified. Sample 123-765B-18-CC belongs in nannofossil Zone CN9 (Discoaster quinqueramus) indicating an age greater than 5.6 Ma. Therefore the normal-polarity interval in Core 123 $765 \mathrm{~B}-18 \mathrm{H}$ may be Chron C3An of latest Miocene age.

The chronostratigraphy of Miocene sediments in Hole 765B is based entirely on calcareous nannofossils and planktonic foraminifers. The boundary between upper and middle Miocene was placed within Core 123-765B-38X, based on the occurrence of poorly preserved planktonic foraminiferal assemblages belonging to Zones N13 to N15. Nannofossil assemblages belonging to Zone CN6 (Catinaster coalitus Zone), which spans the boundary between upper and middle Miocene were observed in Core 123 765B-36X. The high frequency of magnetic reversals during the Miocene (more than 30 ) made the task of identifying individual reversals difficult. Therefore, polarity chrons have been only tentatively assigned in Figure 5. Chron $\mathrm{C} 3 \mathrm{Ar}$ and $\mathrm{C} 3 \mathrm{Br}$ probably extend from the base of Core 123-765B-18H to Core 123-765B-27X. Chron C4Ar probably includes Cores $123-765 \mathrm{~B}-28 \mathrm{X}$ to $-33 \mathrm{X}$. The remainder of Hole 765B was assigned to Chron C5r.

\section{Hole 765C}

Because of poor recovery near the base of Hole 765B, Leg 123 scientists decided to begin coring in Hole $765 \mathrm{C}$ about $50 \mathrm{~m}$ above the bottom of Hole 765B. The upper part of Hole 765C, therefore, contains the same Miocene calcareous turbidites as those discussed above. Deeper in the hole, the amount of pelagic sediments increases, and the preservation of microfossils improves. In comparison to the Neogene sediments, Paleogene and Upper Cretaceous sediments are highly condensed, but contain a good record of nannofossils and planktonic foraminifers that allows for precise dating. Aptian to Cenomanian sediments still contain calcareous microfossils, but Neocomian to uppermost Jurassic sediments are largely noncalcareous. However, these sediments do contain biosiliceous intervals with well-preserved radiolarians. The chronostratigraphy of the Neocomian to uppermost Jurassic interval is based on a combination of nannofossils, radiolarians, palynomorphs, and benthic foraminifers.

The chronostratigraphy of Hole $765 \mathrm{C}$ is constrained by a total of 80 biostratigraphic and magnetostratigraphic events (Table 2). These events, together with the ones from Hole 765B, were used to construct an age-vs.-depth plot (Fig. 6) that yields apparent sedimentation rates. A magnetobiostratigraphic summary of Hole $765 \mathrm{C}$ is presented in Figures $7 \mathrm{~A}$ and $7 \mathrm{~B}$. Because of rapidly 


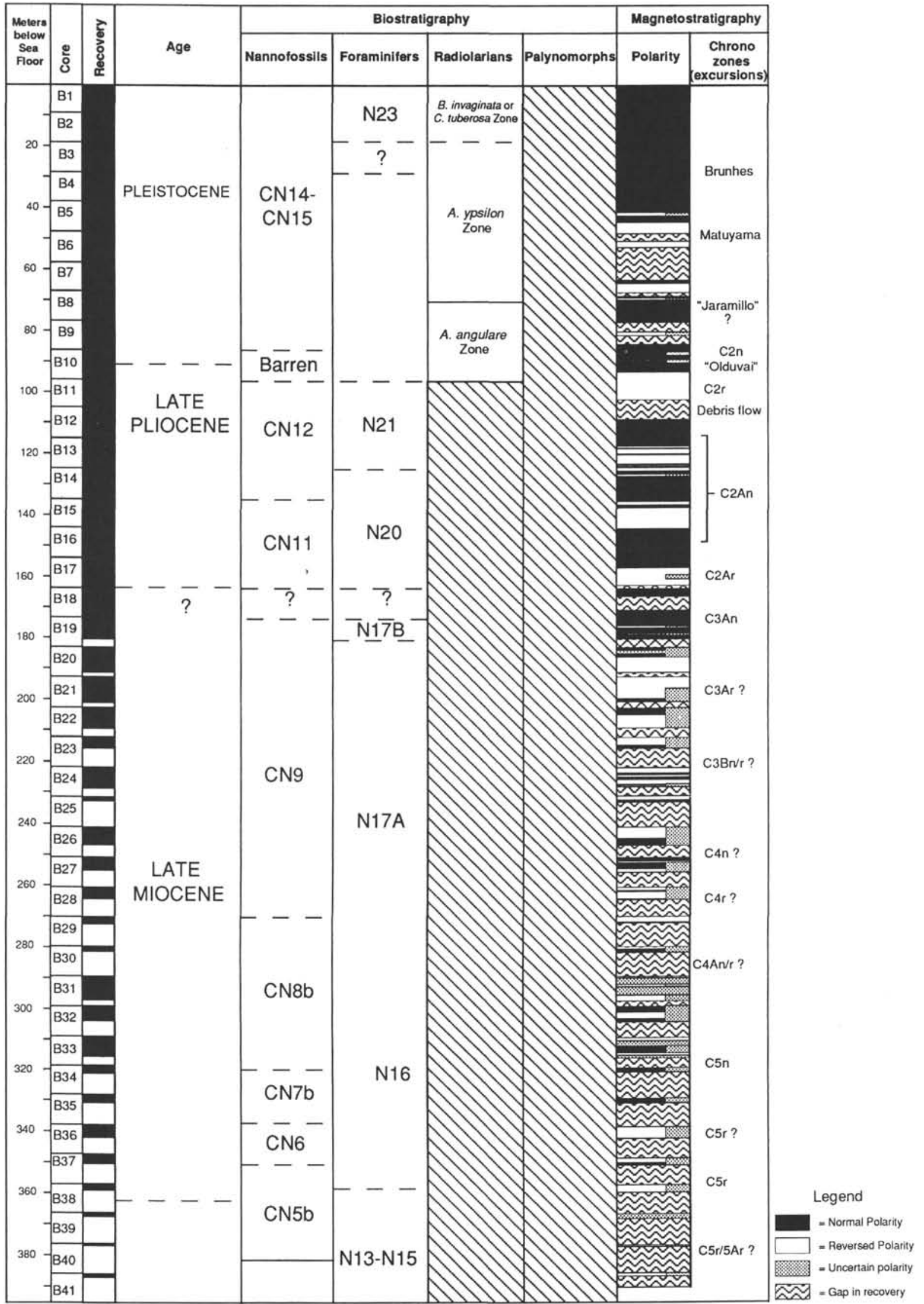

Figure 5. Magnetobiostratigraphic synthesis and chronostratigraphy of Hole 765B. 


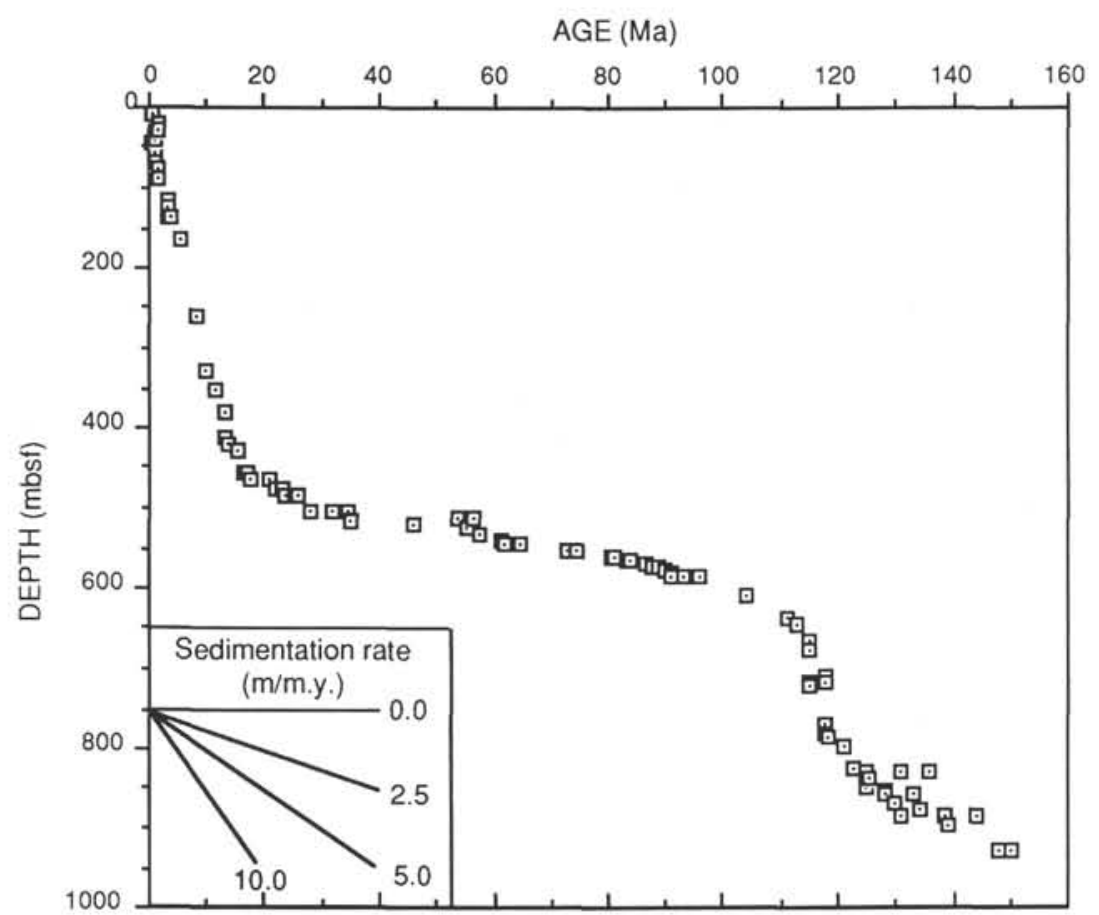

Figure 6. Age-depth curves for Holes $765 \mathrm{~B}$ and $765 \mathrm{C}$, derived from magnetobiostratigraphic data in Tables 1 and 2.

changing sedimentation rates caused by turbidites and the presence of several hiatuses, the magnetic polarity chron assignments are tentative, and are based on the GPTS (Fig. 2).

\section{Cenozoic}

Calcareous turbidites recovered in the upper 12 cores of Hole $765 \mathrm{C}$ are assigned to the middle Miocene, based on nannofossils and planktonic foraminifers. Samples 123-765C-11R-CC and -12-CC belong in planktonic foraminifer Zone N8 (lower part of middle Miocene). This age is supported by calcareous nannofossil Zone CN4. The boundary between the lower and middle Miocene was placed within the debris flow recovered in Core 123-765C13R. Sample 123-765C-13R-CC contains well-preserved lower Miocene assemblages with Globoquadrina binaiensis, Catapsydrax unicavus, and Catapsydrax dissimilis, belonging to planktonic foraminifer Zone N5, as well as the nannofossils Sphenolithus heteromorphus and Calcidiscus macintyrei, which indentify Zone CN4. Approximately at the level of the early/middle Miocene debris flow, an abrupt change in the sedimentation rate was observed, from about $26.6 \mathrm{~m} / \mathrm{m}$.y. in the middle and upper Miocene to approximately $1.8 \mathrm{~m} / \mathrm{m}$.y. in the lower Miocene and Paleogene. Sample 123-765C-14R-CC was assigned to the planktonic foraminiferal Zone N4B (basal Miocene) and to nannofossil Subzone CN1c (Discoaster druggi), based on the presence of $D$. druggi and the absence of $S$. belemnos. This indicates a condensed horizon or hiatus is present within Core $123-765 \mathrm{C}-14 \mathrm{R}$, and represents at least $4.4 \mathrm{~m} . \mathrm{y}$. The Oligocene/Miocene boundary was placed within Core 123-765C-15X. Sample 123-765C-16R-4, 94-96 cm, contains Globigerinoides primordius and Globigerina angulisuturalis, which identify the uppermost Oligocene planktonic foraminiferal Zone N4A. Sample 123-765C-16R-CC was assigned to upper Oligocene nannofossil Zone CP19b (Dictyococcites bisectus), based on the presence of Sphenolithus ciperoensis and the absence of $S$. distentus. Samples 123-765C-17R-1, $70-71 \mathrm{~cm}$, through $123-765 \mathrm{C}-18 \mathrm{R}-1,39-40 \mathrm{~cm}$, were assigned to Subzone CP19a (Cyclicargolithus floridanus), based on the presence of Sphenolithus ciperoensis with $S$. distentus. The lower
Oligocene is represented in Sample 123-765C-18R-2, 134-136 $\mathrm{cm}$, which was placed in nannofossil Subzone CP16c (Reticulofenestra hillae), based on the occurrence of $R$. umbilicata and common Helicopontosphaera reticulata and the absence of Ericsonia formosa and $S$. distentus. This suggests an extremely condensed section or hiatus is present within the upper part of Core 123-765C-18R that represents approximately $4.4 \mathrm{~m} . \mathrm{y}$. of no deposition.

Eight reversed polarity zones were recognized in Cores 123$765 \mathrm{C}-15 \mathrm{R}$ to $-18 \mathrm{R}$. Magnetic polarity zones in Core $123-765 \mathrm{C}$ $16 \mathrm{R}$ may be correlated with Chrons $\mathrm{C} 7$ or $\mathrm{C} 7 \mathrm{~A}$, and the three reversals recorded in Core $123-765 \mathrm{C}-17 \mathrm{R}$ may be correlated with Chron C8r, Subchron C9-1r, and Chron C9r. Because of the hiatus in Core $123-765 \mathrm{C}-18 \mathrm{R}$, the polarity zones may be correlative with Chrons $\mathrm{C} 12$ through $\mathrm{C} 12 \mathrm{r}$.

The boundary between Eocene and Oligocene is represented by a significant turnover in nannofossil assemblages within Section 123-765C-19R-1. Sample 123-765C-19R-1, 128-129 cm, is placed in lower Oligocene Subzone CP16b (E. formosa), but Sample 123-765C-19-2, 105-109 cm, belongs in Subzone CP15b (Isthmolithus recurvus), based on the FO of $R$. umbilica and $I$. recurvus. The next sample $(123-765 \mathrm{C}-19 \mathrm{R}-2,120 \mathrm{~cm})$ contains lower Eocene sediments assigned to nannofossil Subzone CP12a (Discoasteroides kuepperi), based on the presence of Discoaster sublodoensis and D. kuepperi and the absence of Nannotetrina quadrata. This indicates a hiatus is present in Section 123-765C19R-2 that spans at least 13.7 m.y. The lowest Eocene sample is 123-765C-20R-CC, which was placed in Subzone CP9b (Discoaster binodosus), based on the FOs of Tribrachiatus orthostylus and Discoaster diastypus, and the absence of D. lodoensis. Because of the hiatuses and poor recovery in Cores 123-765C-19R to $-21 \mathrm{R}$, the magnetic-polarity reversal pattern was difficult to interpret.

The Paleocene is represented in Cores 123-765C-21R and -22R. Sample 123-765C-21R-1, 16-17 cm, contains a nannoflora of late Paleocene age and was placed in Zone CP8 (Discoaster multiradiatus), based on the presence of Fasciculithus tympani- 
Table 2. Chronostratigraphy of Hole $765 \mathrm{C}$, showing 80 biostratigraphic and magnetostratigraphic events.

\begin{tabular}{|c|c|c|c|c|c|}
\hline & Datum/zone & Interval & $\begin{array}{l}\text { Age } \\
\text { (Ma) }\end{array}$ & Chronostratigraphy & Reference \\
\hline $\mathrm{F}$ & FO Globigerina nepenthes & $1 \mathrm{R}, \mathrm{CC}$ to $2 \mathrm{R}, \mathrm{CC}$ & 11.3 & middle Miocene & Berggren et al., 1985 \\
\hline $\mathrm{N}$ & FO Catinaster coalitus & $1 \mathrm{R}, \mathrm{CC}$ to $2 \mathrm{R}, \mathrm{CC}$ & 11.3 & middle Miocene & Berggren et al., 1985 \\
\hline $\mathrm{N}$ & FO Discoaster kugleri & $4 \mathrm{R}, \mathrm{CC}$ to $6 \mathrm{R}, \mathrm{CC}$ & 13.1 & middle Miocene & Berggren et al., 1985 \\
\hline $\mathrm{F}$ & FO Globorotalia fohsi & $7 R-2,126$ to $8 R-2,76$ & 13.1 & middle Miocene & Berggren et al., 1985 \\
\hline $\mathrm{F}$ & FO Globorotalia praefohsi & $8 \mathrm{R}-2,76$ to $8 \mathrm{R}, \mathrm{CC}$ & 13.9 & middle Miocene & Berggren et al., 1985 \\
\hline $\mathrm{F}$ & FO Orbulina suturalis & $9 \mathrm{R}, \mathrm{CC}$ to $10 \mathrm{R}, \mathrm{CC}$ & 15.2 & middle Miocene & Berggren et al., 1985 \\
\hline $\mathrm{F}$ & FO Globigerinoides sicanus & $12 \mathrm{R}, \mathrm{CC}$ to $13 \mathrm{R}, \mathrm{CC}$ & 16.6 & earliest middle Miocene & Berggren et al., 1985 \\
\hline $\mathrm{N}$ & FO Sphenolithus heteromorphus & $12 \mathrm{R}, \mathrm{CC}$ to $13 \mathrm{R}, \mathrm{CC}$ & 17.1 & late early Miocene & Berggren et al., 1985 \\
\hline $\mathrm{F}$ & LO Catapsydrax dissimilis & $12 \mathrm{R}, \mathrm{CC}$ to $13 \mathrm{R}, \mathrm{CC}$ & 17.6 & late early Miocene & Berggren et al., 1985 \\
\hline $\mathrm{F}$ & FO Globigerinoides altiaperturus & $13 \mathrm{R}, \mathrm{CC}$ to $14 \mathrm{R}, \mathrm{CC}$ & 20.9 & early Miocene & Berggren et al., 1985 \\
\hline $\mathrm{F}$ & LO Globorotalia kugleri & $13 \mathrm{R}, \mathrm{CC}$ to $14 \mathrm{R}, \mathrm{CC}$ & 21.8 & early Miocene & Berggren et al., 1985 \\
\hline $\mathrm{F}$ & FO G. kugleri & $15 \mathrm{R}, \mathrm{CC}$ to $16 \mathrm{R}, \mathrm{CC}$ & 23.7 & Oligocene/Miocene & Berggren et al., 1985 \\
\hline $\mathrm{N}$ & FO Discoaster druggi & $14 \mathrm{R}, \mathrm{CC}$ to $16 \mathrm{R}-1,132$ & 23.2 & earliest Miocene & Berggren et al., 1985 \\
\hline $\mathrm{N}$ & LO Sphenolithus ciperoensis & $14 \mathrm{R}, \mathrm{CC}$ to $16 \mathrm{R}-1,132$ & 25.2 & latest Oligocene & Berggren et al., 1985 \\
\hline $\mathrm{F}$ & FO Globigerinoides primordius & $15 \mathrm{R}, \mathrm{CC}$ to $16 \mathrm{R}-4,95$ & 25.8 & latest Oligocene & Berggren et al., 1985 \\
\hline $\mathrm{N}$ & LO Sphenolithus distentus & $17 \mathrm{R}-1,70$ to $17 \mathrm{R}-2,79$ & 28.2 & late Oligocene & Berggren et al., 1985 \\
\hline $\mathrm{N}$ & FO $S$. distentus & $18 \mathrm{R}-1,39$ to $18 \mathrm{R}-2,39$ & 34.2 & early Oligocene & Berggren et al., 1985 \\
\hline $\mathrm{F}$ & FO Globigerina angulisuturalis & $18 \mathrm{R}-1,5$ to $18 \mathrm{R}, \mathrm{CC}$ & 31.6 & late early Oligocene & Berggren et al., 1985 \\
\hline $\mathrm{F}$ & LO Pseudohastigerina & $18 \mathrm{R}-1,5$ to $18 \mathrm{R}, \mathrm{CC}$ & 34 & early Oligocene & Berggren et al., 1985 \\
\hline $\mathrm{N}$ & LO Reticulofenestra umbilicata & $18 \mathrm{R}-1,39$ to $18 \mathrm{R}-2,134$ & 34.6 & early Oligocene & Berggren et al., 1985 \\
\hline $\mathrm{N}$ & LO Isthmolithus recurvus & $19 \mathrm{R}-1,105$ to $19 \mathrm{R}-1,128$ & 34.9 & early Oligocene & Berggren et al., 1985 \\
\hline $\mathrm{F}$ & LO Morozovella aragonensis & $18 \mathrm{R}, \mathrm{CC}$ to $19 \mathrm{R}, \mathrm{CC}$ & 46 & middle Eocene & Berggren et al., 1985 \\
\hline $\mathrm{N}$ & FO Discoaster sublodoensis & $19 \mathrm{R}-3,112$ to $19 \mathrm{R}, \mathrm{CC}$ & 52.6 & latest early Eocene & Berggren et al., 1985 \\
\hline $\mathrm{F}$ & FO $M$. aragonensis & $20 \mathrm{R}-2,52$ to $-2,81$ & 55.2 & early Eocene & Berggren et al., 1985 \\
\hline $\mathrm{N}$ & occ. Tribrachiatus orthostylus & $19 \mathrm{R}-1,11$ & $56.6-53.7$ & early Eocene & Berggren et al., 1985 \\
\hline $\mathrm{N}$ & LO Fasciculithus & $20 \mathrm{R}, \mathrm{CC}$ to $21 \mathrm{R}-1,16$ & 57.4 & latest Paleocene & Aubry et al.. 1988 \\
\hline $\mathrm{N}$ & FO Heliolithus kleinpelli & $22 \mathrm{R}-2,2$ to $22 \mathrm{R}-3,2$ & 61.6 & late Paleocene & Berggren et al., 1985 \\
\hline $\mathrm{N}$ & FO Fasciculithus typaniformis & $22 \mathrm{R}-3,2$ to $22 \mathrm{R}-4,19$ & 62 & earliest late Paleocene & Berggren et al., 1985 \\
\hline $\mathrm{N}$ & FO C. tenuis & $23 \mathrm{R}-1,17$ to $22 \mathrm{R}-4,108$ & 64.8 & early Paleocene & Berggren et al., 1985 \\
\hline $\mathrm{N}$ & LO Tranolithus phacelosus & $23 \mathrm{R}-1,17$ to $22 \mathrm{R}-4,108$ & $73-75.5$ & latest Camp.-earliest Maes. & Sissingh, 1977 \\
\hline $\mathrm{BF}$ & occ. H. ovulum gigantea & $22 \mathrm{R}, \mathrm{CC}$ & $80-66.4$ & mid Camp. to latest Maes. & Geroch and Nowak, 1984 \\
\hline M & Top of Chron C33 & $23 \mathrm{R}-2$ & 74.5 & Campanian/Maestrichtian & Berggren et al., 1985 \\
\hline $\mathrm{N}$ & FO Ceratolithoides aculeus & $23 \mathrm{R}, \mathrm{CC}$ to $24 \mathrm{R}-1,147$ & 80.5 & middle Campanian & Sissingh, 1977 \\
\hline $\mathrm{F}$ & occ. Globotruncana elevata & $24 \mathrm{R}-1$ & $81-84.5$ & early Campanian & Caron, 1985 \\
\hline $\mathrm{N}$ & Aspidolithus parcus-C. obscurus & $24 \mathrm{R}-1$ to $24 \mathrm{R}-3$ & $81-83.5$ & early Campanian & Sissingh, 1977 \\
\hline $\mathrm{N}$ & Calculites obscurus Zone & $24 R-4$ & $83.5-84.5$ & latest Sant.-earliest Camp. & Sissingh, 1977 \\
\hline M & Top Cretaceous quiet zone & $24 \mathrm{R}-3$ & 84 & Campanian/Santonian & Berggren et al., 1985 \\
\hline $\mathrm{F}$ & Dicarinella primitiva Zone & $25 \mathrm{R}-1,103$ & $87.5-88$ & late Coniacian & Caron, 1985 \\
\hline $\mathrm{N}$ & occ. Micula decussata & $25 \mathrm{R}-1,13$ & $86.5-87.5$ & early Santonian & Sissingh, 1977 \\
\hline $\mathrm{N}$ & occ. Marthasterites furcatus & $25 \mathrm{R}-2,46$ & $88.7-88.5$ & Coniacian & Sissingh, 1977 \\
\hline $\mathrm{N}$ & occ. Eiffellithus eximus & $25 \mathrm{R}-3,138$ & $88.5-89.5$ & late Turonian & Sissingh, 1977 \\
\hline $\mathrm{N}$ & Quadrum gartneri Zone & $25 \mathrm{R}-4,140$ to $26 \mathrm{R}-1,25$ & $89.5-91$ & early-mid Turonian & Sissingh, 1977 \\
\hline $\mathrm{F}$ & occ. Marginotruncana sigali & $25 \mathrm{R}, \mathrm{CC}$ & $88.5-89.5$ & late Turonian & Caron, 1985 \\
\hline $\mathrm{N}$ & LO Corollithion kennedyi & $26 \mathrm{R}-1,25$ to $-1,128$ & 91 & late Cenomanian & Perch-Nielsen, 1985 \\
\hline $\mathrm{N}$ & FO C. kennedyi & $26 \mathrm{R}-5,25$ to $26 \mathrm{R}, \mathrm{CC}$ & 96 & early Cenomanian & Perch-Nielsen, 1985 \\
\hline $\mathrm{F}$ & Rotalipora cushmani Zone & $26 \mathrm{R}-4,79$ & 91-93 & latest Cenomanian & Caron, 1985 \\
\hline $\mathrm{BF}$ & LO Plectorecurvoides alternans & $26 \mathrm{R}-4,79$ to $26 \mathrm{R}, \mathrm{CC}$ & 94 & early Cenomanian & Geroch and Nowak, 1984 \\
\hline $\mathrm{N}$ & FO Eiffellithus turriseiffelii & $26 \mathrm{R}-3,32$ to $27 \mathrm{R}-1,90$ & $92-100$ & late Albian-early Cenom. & Sissingh, 1977 \\
\hline $\mathrm{N}$ & FO Tranolithus phacelosus & $28 \mathrm{R}, \mathrm{CC}$ to $29 \mathrm{R}-1$ & 104 & Albian & Perch-Nielsen, 1985 \\
\hline $\mathrm{N}$ & FO Prediscosphaera columnata & $32 \mathrm{R}-1,27$ to $32 \mathrm{R}-$ & 111 & Albian & Sissingh, 1977 \\
\hline $\mathrm{P}$ & FO Canningopsis intermedia & $33 \mathrm{R}-1,38$ to $34 \mathrm{R}-1,130$ & 113 & earliest Albian & Helby et al., 1987 \\
\hline $\mathrm{N}$ & $\begin{array}{l}\text { FO Hayesites albiensis and } \\
\text { E. florialis }\end{array}$ & $34 \mathrm{R}, \mathrm{CC}$ to 35 & 115 & late Aptian & Sissingh, 1977 \\
\hline $\mathbf{P}$ & Diconodinium davidii Zone & $33 \mathrm{R}-1,38$ to $35 \mathrm{R}, \mathrm{CC}$ & $113-115$ & late Aptian & Helby et al., 1987 \\
\hline $\mathrm{F}$ & G. algeriana-H. gorbachikae & $34 \mathrm{R}, \mathrm{CC}$ & $113-115$ & late Aptian & Caron, 1985 \\
\hline $\mathrm{N}$ & FO Praediscosphaera columnata & $36 \mathrm{R}-1,136$ to $36 \mathrm{R}-5,116$ & & early mid Albian & Mutterlose, this volume \\
\hline $\mathrm{N}$ & FO Rutinolithus irregularis & $39 \mathrm{R}-4,30$ to $39 \mathrm{R}-5,4$ & 118 & base Aptian (Chron M0) & Bralower, 1987 \\
\hline $\mathrm{F}$ & LO Hedbergella delrioensis & $39 \mathrm{R}, \mathrm{CC}$ to $40 \mathrm{R}-1,10$ & 118 ? & Aptian & Caron, 1985 \\
\hline $\mathrm{N}$ & FO Chiastozygus litterarius & $40 \mathrm{R}-4,30$ to $40 \mathrm{R}-4,128$ & 118 & base Aptian (Chron M0) & Bralower, 1987 \\
\hline $\mathrm{N}$ & FO Rhagodiscus angustus & $40 \mathrm{R}-4,30$ to $40 \mathrm{R}-4,128$ & 115 & mid Aptian & Thierstein, 1971 \\
\hline $\mathrm{p}$ & Odontochitina operculata & $40 R, C C \& 45 R, C C$ & $115-118$ & early Aptian & Helby et al., 1987 \\
\hline $\mathrm{R}$ & Sethocapsa euganea Zone & $42 \mathrm{R}-3,140$ to $45 \mathrm{R}-5,52$ & & early Aptian & Shaaf, 1985 \\
\hline $\mathrm{F}$ & occ. Caucasella hoterivica & $45 \mathrm{R}, \mathrm{CC}$ & $128-130$ & Haut.-early Aptian & Caron, 1985 \\
\hline $\mathrm{P}$ & upper Muderongia australis Zone & $47 \mathrm{R}-3,139$ to $52-1,150$ & $118-125$ & late Barremian & Helby et al., 1987 \\
\hline M & Top of Chron M0 & $47-1$ or higher & 118 & earliest Aptian & Berggren et al., 1985 \\
\hline M & Bottom of Chron M0 & $47-4,66$ & 118.5 & basal Aptian & Ogg (unpubl. data) \\
\hline $\mathbf{R}$ & LO Pseudodictyomitra lilyae & $48 \mathrm{R}, \mathrm{CC}$ to $49 \mathrm{R}-2,39$ & $\sim 121$ & upper Barremian & Schaaf, 1981 \\
\hline M & Top of Chron M3 & $51 \mathrm{R}-5,131$ & 123 & late mid Barremian & Ogg and Steiner, 1988 \\
\hline $\mathbf{R}$ & FO Eucyrtis tenuis & $52 \mathrm{R}-2,68$ to $52 \mathrm{R}, \mathrm{CC}$ & $\sim 131$ & early Haut. & Sanfilippo and Riedel, 1985 \\
\hline $\mathbf{R}$ & FO Eucyrtis columbaria & $52 \mathrm{R}-2,68$ to $52 \mathrm{R}, \mathrm{CC}$ & 136 & mid Valanginian & Sanfilippo and Riedel, 1985 \\
\hline M & Bottom of Chron M3 & $53 \mathrm{R}-1,76$ & 125.5 & early mid Barremian & Ogg and Steiner, 1988 \\
\hline $\mathbf{P}$ & lower Muderongia australis Zone & $54 \mathrm{R}-4,50 \& 54, \mathrm{CC}$ & $125-128$ & latest Valan.-early Barr. & Helby et al., 1987 \\
\hline $\mathrm{N}$ & $N$. columi-C. oblongata zones & $55 \mathrm{R}-1 \& 58 \mathrm{R}-1$ & $128-144$ & late Berr.-early Haut. & Sissingh, 1977 \\
\hline $\mathrm{N}$ & occ. Cruciellipsis cuvillieri & $55 \mathrm{R}-1,41$ & $>128$ & LAD in Chron M8 & Bralower, 1987 \\
\hline $\mathrm{N}$ & occ. Speetonia colligata & $56 \mathrm{R}-3,142 \& 56 \mathrm{R}-2,60$ & 130 & base Berr.-mid Haut. & Mutterlose, this volume \\
\hline $\mathrm{N}$ & LO Turbodiscus verenae & $55 \mathrm{R}-1,120$ to $55 \mathrm{R}-2,110$ & 133 & Chron M1 1n & Bralower, 1987 \\
\hline BF & occ. Praedorothia praehauteriviana & 56R, CC & $131.5-138.5$ & Valanginian & Kaminski et al., this volume \\
\hline
\end{tabular}


Table 2 (continued).

\begin{tabular}{|c|c|c|c|c|c|}
\hline & Datum/zone & Interval & $\begin{array}{l}\text { Age } \\
(\mathrm{Ma})\end{array}$ & Chronostratigraphy & Reference \\
\hline $\mathrm{R}$ & LO Podocapsa amphitreptera & $56 \mathrm{R}, \mathrm{CC}$ to $57 \mathrm{R}-4,51$ & $\sim 134$ & Iate Valanginian & Schaaf, 1985 \\
\hline $\mathrm{N}$ & FO Turbodiscus verenae & $58 \mathrm{R}-1,85$ to $58 \mathrm{R}-1,131$ & $\sim 138.5$ & Base Valanginian & Bown et al., 1988 \\
\hline $\mathrm{N}$ & FO Lithraphidites carniolensis & $58 \mathrm{R}-1,131$ to $58 \mathrm{R}-2,140$ & 144 & base Berriasian & Perch-Nielsen, 1985 \\
\hline $\mathbf{R}$ & LO Obesocapsula rotunda & $58 \mathrm{R}-3,31$ to $58 \mathrm{R}-3,89$ & 131 & Iate Hauterivian & Schaaf, 1985 \\
\hline $\mathrm{P}$ & Batioladinium reticulatum Zone & $59 \mathrm{R}-4,105 \& 59 \mathrm{R}-5,8$ & $>139$ & late Berriasian & Helby et al., 1987 \\
\hline $\mathrm{N}$ & FO Microstaurus chiastius & $62 \mathrm{R}-1,53$ to $62-4,25$ & $\sim 150$ & middle Tithonian & Bralower et al., 1989 \\
\hline $\mathrm{R}$ & FO Holocryptocanium barbui & $62 \mathrm{R}-1,53$ to $62-4,25$ & $\sim 148$ & late Tithonian-early Berrias. & Baumgartner, this volume \\
\hline
\end{tabular}

formis, Toweius eminens, Chiasmolithus bidens, Discoaster nobilis, D. mohleri, and rare D. multiradiatus in the absence of $D$. diastypus. The upper portion of Core 123-765C-22R belongs in Zones CP5 to CP6, based on the co-occurrence of $F$. tympaniformis, T. eminens, Heliolithus kleinpelli, and very rare D. mohleri in Sample 123-765C-22R-2, $2 \mathrm{~cm}$. Lower in the core, Sample 123-765C-22R-3, 2-3 cm, was placed in Zone CP4 (F. tympaniformis) based on the presence of the nominate species in the absence of $\mathrm{H}$. kleinpelli. The FO of Cruciplacolithus tenuis in Sample 123-765C-22R-4, $108 \mathrm{~cm}$, indicates the presence of nannofossil Zone CP1b (C. tenuis).

\section{Upper Cretaceous}

The Cretaceous/Tertiary boundary is located in an interval of condensed, noncalcareous claystones in Section 123-765C-22R5. The highest sample of undoubted Cretaceous age is Sample 123-765C-22R-CC. This sample is barren of calcareous microfossils, but yielded an agglutinated foraminiferal assemblage with Hormosina ovulum gigantea and Bolivinoides parvissimus, belonging to the late Campanian to Maestrichtian $H$. ovulum gigantea Zone of Geroch and Nowak (1984). The last occurrence of $H$. ovulum gigantea is an excellent indicator of the $\mathrm{K} / \mathrm{T}$ boundary in the Atlantic region (Berggren and Kaminski, 1990). However, the presence of $B$. parvissimus suggests that Sample 123-765C-22P.$\mathrm{CC}$ may be from the lower part of the $H$. ovulum gigantea Zone (upper Campanian to lower Maestrichtian), based on comparisons to Atlantic Ocean Site 543 (Hemleben and Troester, 1985). The highest level with exclusively Cretaceous plankton is Sample 123-765C-23R-1, $17 \mathrm{~cm}$. This sample contains Quadrum trifidum, Reinhardtites levis, $Q$. gothicum, and Ceratolithoides aculeus, which are characteristic of nannofossil Zone CC23 $(Q$. trifidum and $T$. phacelosus). Because Aspidolithus parcus constrictus, a species whose LO marks the Campanian/Maestrichtian boundary, is present in this assemblage, the sample may be assigned a Campanian age. Therefore, the entire lower Danian and Maestrichtian may be represented by the condensed noncalcareous interval in Section 123-765C-22R-5.

The Upper Cretaceous in Hole $765 \mathrm{C}$ is represented by a $30-\mathrm{m}-$ thick condensed section of claystone and fine-grained calcareous turbidites between Sections 123-765C-23R-1 and 123-765C-26R1 , deposited with an average sedimentation rate of $1.7 \mathrm{~m} / \mathrm{m} . \mathrm{y}$. Nannofossil zones in the Turonian to Maestrichtian have estimated durations of between 1.0 and $2.5 \mathrm{Ma}$ and provide the best chronostratigraphic resolution.

The interval between Samples 123-765C-23R-2, $20 \mathrm{~cm}$, and 123-765C-23R-CC is of late Campanian age (C. aculeus Zone CC20 to $Q$. trifidum Zone CC22), based on the presence of $C$. aculeus, $Q$. gothicum, R. levis, A. parcus constrictus, and Eiffellithus eximus. The early Campanian (A. parcus Zone CC18 and $C$. ovalis Zone CC19) is represented by the occurrence of $R$. anthrophorus, E. eximius, $M$. furcatus, A. parcus, and A. parcus constrictus from Samples 123-765C-24R-1, $147 \mathrm{~cm}$, to 123-765C$24 \mathrm{R}-3,57 \mathrm{~cm}$. The reversed-polarity zones located in the upper portion of Core $123-765 \mathrm{C}-23 \mathrm{R}$ are probably correlative with Chrons C32.1r or C32r. Accordingly, the reversed-polarity zone within Sections 123-765C-24R-2 and -24R-3 may be Chron 33r of Campanian age.

Santonian nannofloras were recovered from Sections 123765C-24R-4 to 123-765C-25R-1. Diagnostic species in this interval are Quadrum gartneri, $M$. decussata, $R$. anthophorus, and $M$. furcatus, including Lithastrinus septenarius in Sample 123-765C24R-CC, which indicate the presence of Zones CC14 (M. decussata) to CC15 (R. anthophorus) or possibly even CC17 (C. obscurus). Because the genera Lucianorhabdus and Calculites are rare or absent, it is not clear whether Zones CC16 (L. maleformis) and $\mathrm{CC} 17$ (C. obscurus) are absent or simply unrecognizable because of environmental factors. If these zones are missing, a hiatus is present between the upper lower Santonian Zone CC15 and the lower Campanian Zone CC18.

The Coniacian is present in the upper portion of Core 123$765 \mathrm{C}-25 \mathrm{R}$. The presence of a planktonic foraminiferal assemblage dominated by Dicarinella was found in Sample 123-765C25R-1, 103-105 cm. This sample contains $D$. algeriana and $D$. canaliculata, together with Marginotruncana pseudolinneiana, and belongs in the Coniacian Dicarinella primitiva Zone of Caron (1985).

The Turonian is present in the lower portion of Core 123765C-25R and the first section of Core 123-765C-26R. Samples 123-765C-25R-4, $140 \mathrm{~cm}$, and 123-765C-26R-1, $25 \mathrm{~cm}$, were assigned to nannofossil Zone CC11 (Q. gartneri) based on the presence of $Q$. gartneri, E. turriseiffelii, E. floralis, and L. moratus.

The Cenomanian/Turonian boundary corresponds to the interval of dark reddish and interbedded black shales in Section 123$765 \mathrm{C}-26 \mathrm{R}-1$, between 50 and $115 \mathrm{~cm}$. The highest Cenomanian nannofossil assemblage was observed in Sample 123-765C-26R-1, $128 \mathrm{~cm}$, which contains Corollithion kennedyi, indicating Zone $\mathrm{CC} 10$ (Microrhabdulus decoratus). The upper Cenomanian is still present in Sample 123-765C-26R-4, 79-84 cm, which contains a planktonic foraminiferal assemblage with Rotalipora greenhornensis, $R$. reicheli, $R$. appenninica, Praeglobotruncana stephani, $P$. gibba, and $P$. delrioensis. This assemblage contains elements of the Rotalipora reicheli and Rotalipora cushmani zones of Caron (1985).

\section{Lower Cretaceous}

The Albian/Cenomanian boundary lies between Sample 123765C-26R-5, 25-26 cm, and Sample 123-765C-27R-1, 30-31 cm. The FO of $C$. kennedyi, which approximates the Zone CC9/CC10 boundary, was observed in Sample 123-765C-26R-5, 25-26 cm, whereas Section 123-765C-27R-1 contains the FO of E. turriseiffelii, which marks the base of Zone CC9. The interval between Samples 123-765C-27R-1, $89 \mathrm{~cm}$, and 123-765C-32R-1, $110 \mathrm{~cm}$, lies in Zone CC8 ( $P$. columnata), which is of Albian age.

The Aptian/Albian boundary is contained within nannofossil Zone CC7b (C. litterarius). This zone was recognized between Samples 123-765C-32R-1, $110 \mathrm{~cm}$, and 123-765C-34R-CC. However, the highest dinoflagellate assemblages observed in the hole, in Sample 123-765C-33R-1, 38-40 cm, are upper Aptian based on the occurrence of Diconodinium davidii and Pseudoceratium turneri. 
A

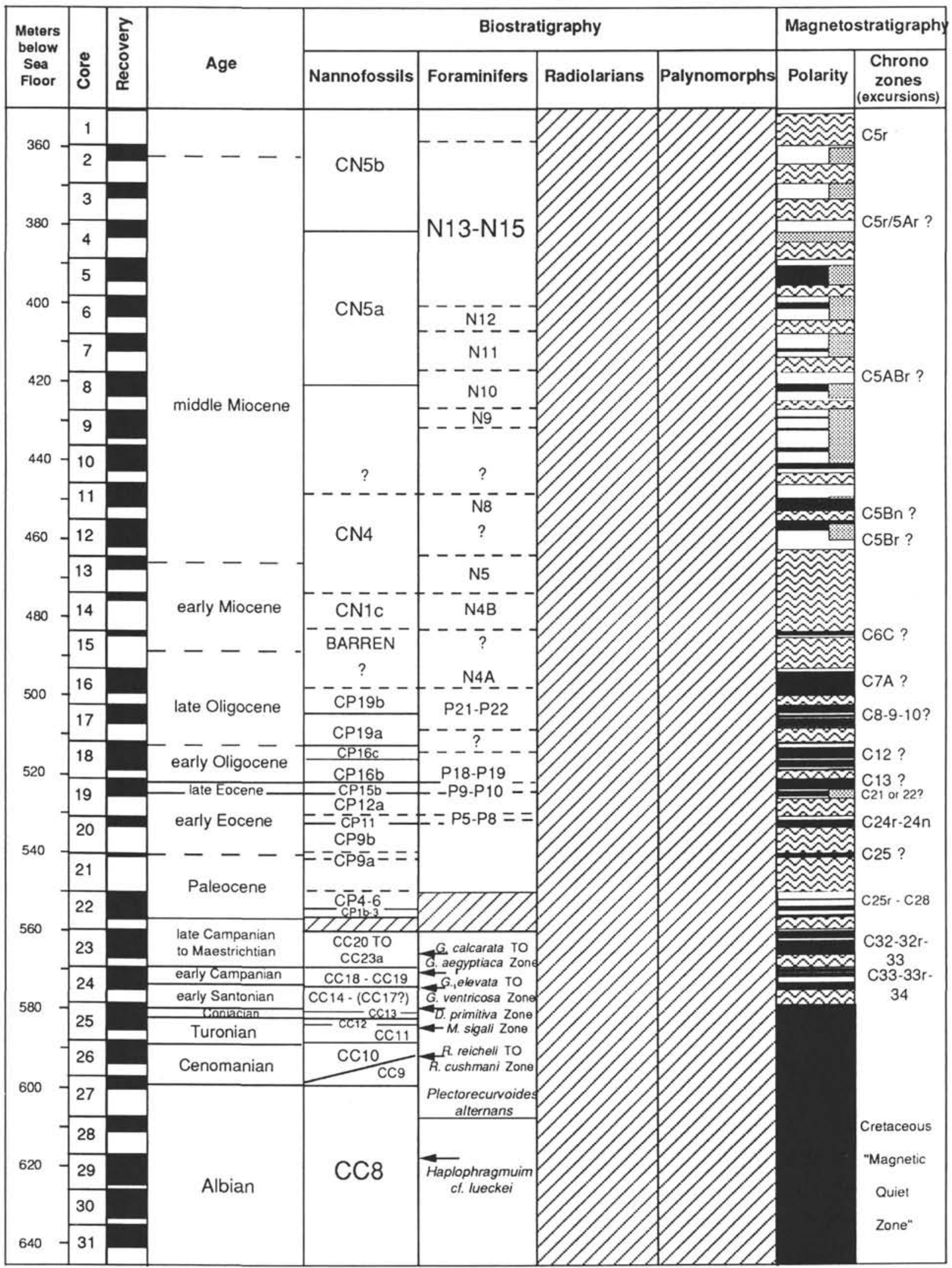

Figure 7. Magnetobiostratigraphic synthesis and chronostratigraphy of Hole 765C (in two parts). A. Middle Miocene to Albian. B. Albian to Tithonian. 
B

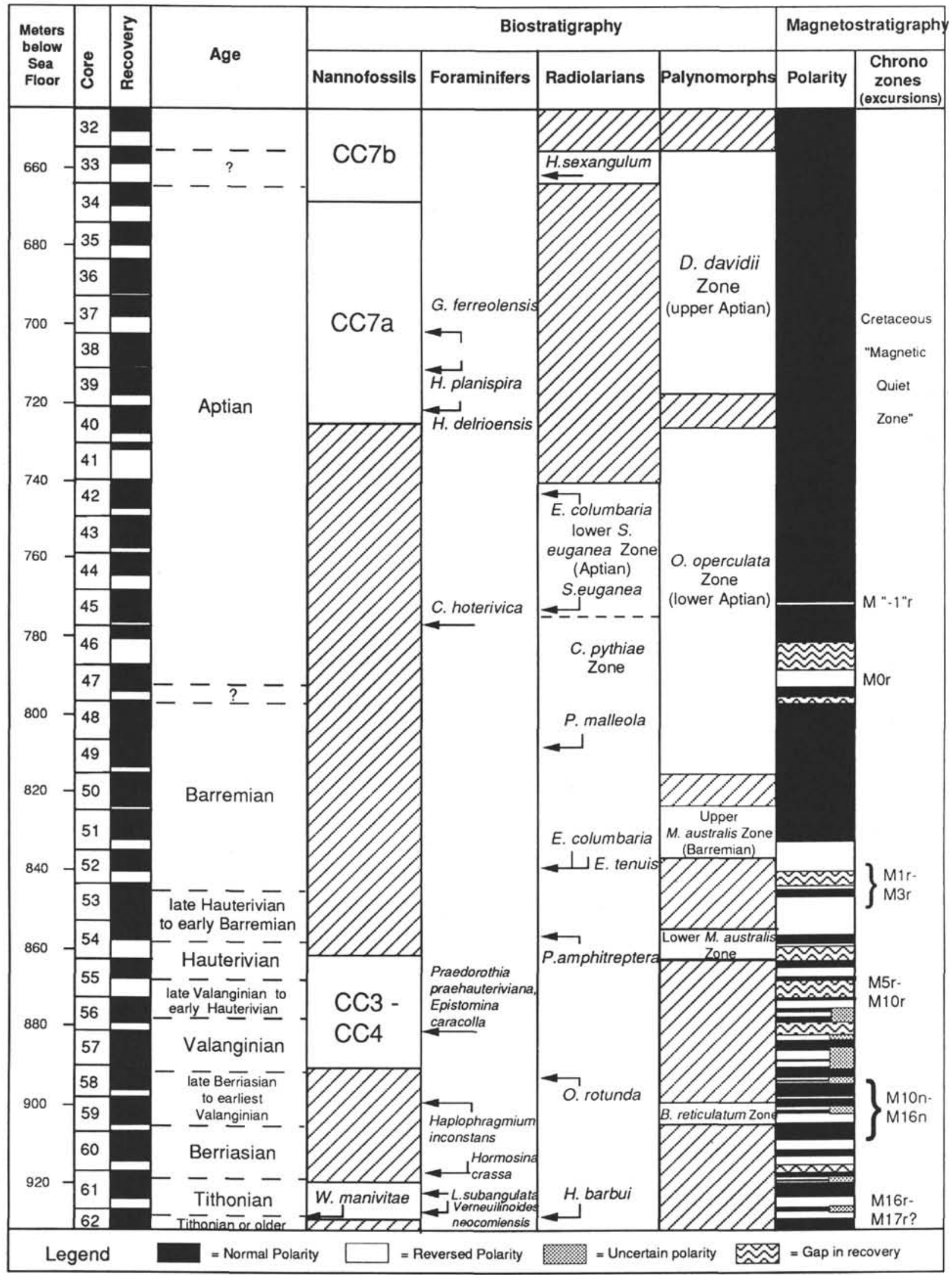

Figure 7 (continued). 
These assemblages are equivalent to the upper Aptian D. davidii Zone of Helby et al. (1987). This sample, however, already displays features that are transitional to the overlying Muderongia tetracantha Zone, which spans the Aptian/Albian boundary. An upper Aptian nannofossil assemblage was observed in Sample 123-765C-40R-4, $30 \mathrm{~cm}$. This assemblage consists of Rhagodiscus angustus, C. litterarius, Eprolithus apertior, E. varolii, and Flabellites biforaminis. The FO of $R$. angustus defines the base of the upper Aptian R. angustus Zone of Perch-Nielsen (1985), while the other species have their FOs in the lower Aptian. However, most samples from Cores $123-765 \mathrm{C}-41 \mathrm{R}$ through 123 $765 \mathrm{C}-54 \mathrm{R}$ are barren of nannofossils, so we probably did not observe the FOs of these species. The interval between Samples 123-765C-40R-4, 138-140 cm, and 123-765C-49R-CC contains the dinoflagellate Odontochitina operculata, but lacks $D$. davidii and $P$. turneri and is equivalent to the lower Aptian $O$. operculata Zone of Helby et al. (1987). The interval between Sample 123$765 \mathrm{C}-42 \mathrm{R}-3,60-62 \mathrm{~cm}$, and $123-765 \mathrm{C}-45 \mathrm{R}-5,52-55 \mathrm{~cm}$, yields abundant, moderately well-preserved radiolarian assemblages assignable to the lower Sethocapsa euganea Zone (Schaaf, 1985), indicating an early Aptian age. The highest reversed-polarity zone in the Lower Cretaceous of Hole $765 \mathrm{C}$ is a narrow, but clearly defined, event spanning only $43 \mathrm{~cm}$ in Section 123-765C-45R-2 (Ogg et al., this volume). This event corresponds to $\mathrm{M}$ " -1 " $\mathrm{r}$, which has been correlated to the late Aptian G. algerianus foraminiferal Zone (Vandenberg and Wonders, 1980). The Barremian/Aptian boundary is placed near the base of Core 123-765C$47 \mathrm{R}$, based on magnetostratigraphy. Polarity Chron M0r, marking the base of the Cretaceous quiet zone, is observed in a 4-m-thick interval from Samples 123-765C-47R-1, $95 \mathrm{~cm}$, to $123-765 \mathrm{C}$ $47 \mathrm{R}-4,66 \mathrm{~cm}$. The Barremian/Aptian stage boundary, which occurs just prior to Chron M0 (Channell et al., 1979), is therefore near the base of Core 123-765C-47R. According to Helby et al. (1987), the palynological Barremian/Aptian boundary can be placed at the boundary between the $O$. operculata Zone and the underlying Muderongia australis Zone. The highest occurrence of the $M$. australis Zone, characterized by the absence of $O$. operculata and an abundance of Herendeenia postprojecta, was observed in Sample 123-765C-50-CC. A radiolarian assemblage recovered from Sample 123-765C-49R-2, 39-43 cm, contains the FO of (?)Parvicingula malleola, together with Eucyrtis tenuis, E. columbaria, and Sethocapsa leiostraca. This assemblage is characteristic of the upper Barremian. A radiolarian assemblage in Sample 123-765C-52R-2, 68-71 cm, contains the FOs of Eucyrtis tenuis and E. columbaria, indicating a late Hauterivian to early Barremian age. Samples 123-765C-54R-4, 49-50 cm, and -54RCC contain the dinoflagellate Phoberocysta neocomica, indicating the lower $M$. australis Zone, which has been reported as late Hauterivian to Barremian in age (Helby et al., 1987). However, these samples are still of Barremian age, based on magnetostratigraphy. The base of polarity Chron M3 was observed in Sample 123-765C-53R-1, $76 \mathrm{~cm}$. This correlates with the lower mid-Barremian, according to Ogg and Steiner (1988).

Because of patchy preservation and the lack of distinctive microfossils, our placement of chronostratigraphic boundaries beneath Chron M3 in Core 123-765C-53R is approximate and is based mainly on interpolation using the sediment accumulation rate curve (Kaminski et al., this volume). The highest Hauterivian nannofossil assemblage was found in Sample 123-765C-56R-1, $85 \mathrm{~cm}$. This sample contains the highest occurrence of Cruciellipsis cuvillieri, which according to Bralower (1987) ranges no higher than Chron M8 (upper Hauterivian). This age is corroborated by the occurrence of Speetonian colligata in Sample 123$765 \mathrm{C}-56 \mathrm{R}-2,60-61 \mathrm{~cm}$. In other areas, $S$. colligata ranges from the base of the Berriasian to the middle Hauterivian (Mutterlose, this volume). The LO of the radiolarian Obesacapsula rotunda was observed in Sample 123-765C-58R-3, 89-93 cm, indicating an age no younger than late Hauterivian.

We were unable to precisely delineate the Valanginian/Hauterivian and Berriasian/Valanginian boundaries biostratigraphically because of the lack of biostratigraphic markers and the presence of barren intervals. The highest Hauterivian nannofossil assemblage was observed in Sample 123-765C-55R-3, $50 \mathrm{~cm}$, indicated by the presence of the nannofossils Tegumentum tripes (=Eiffellithus windii auct. $)$ and Cruciellipsis cuvillieri. The interval from the top of Core 123-765C-55R to the middle of Core $123-765 \mathrm{C}-56 \mathrm{R}$ was assigned a late Valanginian to Hauterivian age, based on the LO of Turbodiscus verenae in Sample 123-765C$56 \mathrm{R}-3,142 \mathrm{~cm}$. An early Valanginian age was assigned to Section 123-765C-58R-1, based on the FOs of $T$. tripes in Sample 123765C-58R-1, $56 \mathrm{~cm}$, and $T$. venerae in Sample 123-765C-58R-1, $85 \mathrm{~cm}$. In the Umbrian Apennines, the first occurrence of these species is in the lower Valanginian (Bralower et al., 1989). Another useful tie point is provided by the occurrence of the upper Berriasian Batioladinium reticulatum Zone of Helby et al. (1987) in Samples 123-765C-59R-4, 105-112 cm, and 123-765C-59R-5, $8-9 \mathrm{~cm}$.

Basaltic basement was encountered at a depth of $931.2 \mathrm{mbsf}$ in Section 123-765C-62R-4. Samples taken directly above basement (i.e., 123-765C-62R-2, $13 \mathrm{~cm}$, to $123-765 \mathrm{C}-62 \mathrm{R}-4,31 \mathrm{~cm}$ ) are barren of nannofossils. Although the base of the sedimentary section in Hole $765 \mathrm{C}$ was originally described as upper Berriasian based on shipboard biostratigraphic analyses (e.g. Shipboard Scientific Party, 1990; von Rad et al., 1989), more detailed analyses of nannofossils in Cores 123-765C-61R and the upper portion of Core $123-765 C-62 R$ yield a Tithonian age, based on the occurrence of abundant, large Watznaureria manivitae (=Cyclogelosphaera deflandrei auct.), which correlates well with similar Tithonian assemblages in Hole 261 (Dumoulin and Bown, this volume). The lowest nannofossil assemblage was observed in Sample $123-765 C-62 \mathrm{R}-2,13 \mathrm{~cm}$. This sample contained a poorly preserved, low-diversity assemblage with Watznaureria manivitae, W. barnsae, W. britannica, W. fossaoincta, Cyclagelosphaera deflandrei, Microstaurus chiastius, and M. quadratus. These species cannot pinpoint the age of this assemblage, but can provide a lower limit. Bralower et al. (1989) reported $M$. quadratus ranges upward from the middle Tithonian in the Umbrian area of Italy. Mutterlose (this volume) assigned a Tithonian age to this assemblage, based on the absence of Lithraphidites carniolensis and Rotelapillus laffittei, which range upward from the Tithonian/Berriasian boundary in other areas (Perch-Nielsen, 1985). Dumoulin and Bown (this volume) regard this assemblage as Tithonian, based on detailed correlations with DSDP Site 261. The FO of $L$. carniolensis was observed in Sample 123-765C-58R-1, $131 \mathrm{~cm}$. Mutterlose (this volume) does not regard its absence from assemblages lower in the hole to be an artifact of preservation, because the species is present in poorly preserved assemblages higher in the section. However, the lowest radiolarian assemblages in Hole $765 \mathrm{C}$ yield age data that conflict with the nannofossils. The assemblages found in Sample 123-765C-62R-1, 53-56 cm, contain typical specimens of Holocryptocanium barbui, a species that ranges upward from the upper Berriasian in the Tethys region. The presence of Cryptamphorella sp., Xitus sp., Sethocapsa sp., aff. S. cetia, and Archaeodictyomitra sp. aff. A. sliteri, in addition to $H$. barbui, indicate a Cretaceous age according to Baumgartner (this volume). None of these species have been previously recorded in samples of Late Jurassic age, at least in the Tethys region. All the above-mentioned taxa range to the top of Core 123-765C-59R.

The age of those sediments directly above basement is crucial, because we had expected a Kimmeridgian to Oxfordian age of basement from the position of the site on marine magnetic anom- 
aly M26. According to the plate tectonic scenario proposed by Audley-Charles et al. (1988) and Fullerton et al. (1989), the Argo Abyssal Plain at Site 765 formed during the Late Jurassic ( 164 $\mathrm{Ma}$ ), when seafloor spreading transported a long continental block (southern Tibet and Burma) away from northwestern Australia. Assuming that this scenario is correct, a hiatus or an extremely condensed horizon accounting for $15 \mathrm{~m}$.y of no deposition separates the base of the dated sedimentary section in Hole $765 \mathrm{C}$ from oceanic basement. However, Dumoulin and Bown (this volume) point out that the 4.5 -m-thick barren interval beneath the $W$. manivitae Zone in Hole $765 \mathrm{C}$ is thicker than a similar barren interval in Hole 261, which they consider as evidence that the base of Hole 765 is as old, if not older, than the base of Hole 261. Nevertheless, the lack of microfossils having ranges restricted to the Jurassic renders our age assignment for the base of the sedimentary section speculative. This Late Jurassic age for the base of the sedimentary section is based on microfossil absences and lithologic correlations to Site 261.

\section{SITE 766}

Site 766 is located at $19^{\circ} 55.92$ ' $\mathrm{S}, 110^{\circ} 27.24^{\prime} \mathrm{E}$, at the foot of the western escarpment of the Exmouth Plateau, at a water depth of $3997.5 \mathrm{~m}$. The site is situated on marine magnetic anomaly M10, of late Valanginian age. Only one rotary core barrel hole (Hole 766A) was drilled at the site, and because of time limitations, plans for a second APC hole had to be canceled. Drilling in Hole $766 \mathrm{~A}$ recovered $466.7 \mathrm{~m}$ of sediment in 49 cores, with an average recovery of $66 \%$. Sediments range in age from Pleistocene to late Valanginian-early Hauterivian.

Biostratigraphy of Cenozoic and Upper Cretaceous calcareous oozes was accomplished mainly using nannofossils and foraminifers. Radiolarians are present in the Pleistocene and Lower Cretaceous sections. Palynomorphs provide the most detailed biostratigraphic dating from the Barremian to the base of the hole. Magnetostratigraphy produced stable results only in the Lower Cretaceous. Dinoflagellate assemblages yield an age of late Valanginian for sediment directly overlying basement and between diabase sills at the base of the hole. The occurrences of stratigraphically important species are compiled in Table 3, and these were used to construct an age-vs.-depth plot (Fig. 8) that gives the apparent sedimentation rates. A summary of the biostratigraphic and magnetostratigraphic results of Hole $766 \mathrm{~A}$ is presented in Figure 9.

\section{Cenozoic}

Foraminifers and nannofossils are generally well preserved in the Cenozoic, and there is little evidence of reworking. Both nannofossils and planktonic foraminiferal assemblages display a temperate, or mid-latitude, nature. For example, the mid-latitude Amaurolithus delicatus Subzone (CN10d) of Bukry (1981) could be applied, and Globorotalia puncticulata, a good marker species in the northern Atlantic Ocean, is common in the Pliocene. Unfortunately, rotary drilling in the upper portion of the hole disrupted the sedimentary fabric and reset the magnetization. The homogenized outer region of these cores dominated the half-core magnetic polarity measurements, rendering the shipboard NRM results ambiguous.

The Pleistocene is present in Core 123-766A-1R. The corecatcher sample was placed in the Calcidiscus macintyrei Zone of Gartner (1977) based on the presence of this species and the lack of Emiliania huxleyi. Planktonic foraminifers include Globorotalia truncatulinoides and G. tosaensis, indicating an early Pleistocene age.

The Pliocene is represented in Core $123-766 \mathrm{~A}-2 \mathrm{R}$. The corecatcher sample belongs in the Amaurolithus delicatus Subzone
(CN10d) of Bukry (1981), based on the common co-occurrence of Discoaster asymmetricus and Amaurolithus delicatus. The foraminiferal assemblage contains Globorotalia puncticulata (including morphotypes transitional to $G$. inflata), G. margaritae, $G$. nepenthes, Sphaeroidinellopsis seminula, S. kochi, and Dentoglobigerina altispira, indicating the upper portion of Zone N19. The lower Pliocene age of this sample implies a condensed Pliocene section or hiatus of about 2.0 m.y. within Core 123-766A-2R.

A major hiatus representing about 49 m.y. is present within the upper $1 \mathrm{~m}$ of Core 123-766A-3R. The interval between Samples $123-766 \mathrm{~A}-3 \mathrm{R}-1,119 \mathrm{~cm}$, and $-3 \mathrm{R}-5,93 \mathrm{~cm}$, is assigned to Zone CP12 (D. sublodoensis), based on the occurrence of the nominate taxon in association with Discoaster tani and Dictyococcites callidus. Sample 123-766A-3R-CC contains common Camplosphaera eodela, Discoaster lodoensis, and Toweius crassus, indicating the lower Eocene Zone CP11 (D. lodoensis). The foraminiferal assemblage is dominated by Acarinina and includes Morozovella aragonensis and $M$. lensiformis. The presence of these two forms with the absence of $M$. subbotinae, suggests that this sample lies in the upper part of Zone P7 or in Zone P8. Samples $123-766 \mathrm{~A}-4 \mathrm{R}-\mathrm{CC}$ to $-6 \mathrm{R}-5,100 \mathrm{~cm}$, were placed in nannofossil Zone CP9 (D. diastypus), based on the occurrence of C. eodela, Discoaster multiradiatus, and D. diastypus and the lack of $D$. lodoensis. The absence of Tribrachiatus contortus or $T$. orthostylus does not permit further subdivision of this zone. The planktonic foraminiferal assemblage includes Morozovella subbotinae, $M$. marginodentata, $M$. formosa gracilis, and $M$. aequa and is characteristic of Zone P6, which spans the Paleocene/Eocene boundary. The lack of $M$. velascoensis in this assemblage, however, suggests a placement in the lowermost Eocene Subzone P6b.

The Paleocene is represented in Cores $123-766 \mathrm{~A}-6 \mathrm{R}$ to $-9 \mathrm{R}$. Samples from Section 123-766A-6R-7 were placed in nannofossil Subzone P8b (C. eodela), based on the common occurrence of $C$. eodela and $D$. multiradiatus and the absence of $D$. diastypus. The next sample (123-766A-7R-CC) contains D. multiradiatus and Fasciculithus tympaniformis, but lacks C. eodela; it was assigned to Subzone CP8a. Zone CP7 (D. nobilis) was observed in Sample 123-766A-8R-1, 92-95 cm. Sample 123-766A-8R-CC belongs in Zone CP6 (D. mohleri), based on the common occurrence of $D$. mohleri and $F$. tympaniformis and the absence of $D$. nobilis and Heliolithus riedelii. Samples 123-766A-9R-4, 109-111 cm, and 123-766A-9R-5, 109-111 cm, were assigned to Zone CP2 (Chiasmolithus danicus), based on the occurrence of the nominate species. Sample 123-766A-9R-CC was placed in Subzone CP1b (Cruciplacolithus tenuis), based on the presence of common Coccolithus pelagicus and Cruciplacolithus tenuis and the absence of Chiasmolithus danicus. The foraminiferal assemblage in this sample is dominated by reworked Maestrichtian taxa, but contains Subbotina pseudobulloides and S. cf. triloculinoides, which is indicative of lower Paleocene Zone P1b. The early Paleocene age of this sample indicates a condensed horizon or hiatus is present within Core 123-766A-9R. The lowermost Paleocene nannofossil Subzone CP1a (Cruciplacolithus primus) was found in Samples 123-766A-10R-1, $68 \mathrm{~cm}$, and 123-766A-10R-1, $100 \mathrm{~cm}$. This subzone can be recognized by the presence of $C$. primus, $C$. edwardsii, Biantholithus sparsus, and the absence of Cruciplacolithus tenuis. Reworking of Cretaceous plankton increases down Section 123-766A-10R-1. The lowest definitive Paleocene assemblage was found in Sample 123-766A-10R-2, 68-69 cm (Moran, this volume).

\section{Upper Cretaceous}

The chronostratigraphy of Upper Cretaceous sediments in Hole $766 \mathrm{~A}$ is based on calcareous nannofossils and planktonic 
Table 3. Occurrences of stratigraphically important species.

\begin{tabular}{|c|c|c|c|c|c|c|}
\hline & Datum/zone & Interval (cm) & $\begin{array}{l}\text { Age } \\
(\mathrm{Ma})\end{array}$ & Chronostratigraphy & Reference & $\begin{array}{l}\text { Depth } \\
\text { (mbsf) }\end{array}$ \\
\hline $\mathrm{F}$ & LO Globorotalia tosaensis & $1 \mathrm{R}-\mathrm{CC}$ & 0.6 & Pleistocene & Berggren et al., 1985 & 7.7 \\
\hline F & FO Globorotalia truncatulinoides & IR-CC to $2 \mathrm{R}-\mathrm{CC}$ & 1.9 & late Pliocene & Berggren et al., 1985 & 7.7 \\
\hline $\mathrm{N}$ & FO Gyphrocapsa oceanica & $1 \mathrm{R}-\mathrm{CC}$ to $2 \mathrm{R}-\mathrm{CC}$ & 1.68 & latest Pliocene & Berggren et al., 1985 & 7.7 \\
\hline F & LO Globigerina nepenthes & IR-CC to $2 \mathrm{R}-\mathrm{CC}$ & 3.9 & early Pliocene & Berggren et al., 1985 & 17.3 \\
\hline $\mathrm{N}$ & LO Amaurolithus delicatus & $1 \mathrm{R}-\mathrm{CC}$ to $2 \mathrm{R}-\mathrm{CC}$ & 3.7 & early Pliocene & Berggren et al., 1985 & 17.3 \\
\hline $\mathrm{N}$ & FO Discoaster asymmetricus & 2R-CC to $3 \mathrm{R}-\mathrm{CC}$ & 4.1 & early Pliocene & Berggren et al., 1985 & 17.3 \\
\hline F & FO Globorotalia puncticulata & $2 \mathrm{R}-\mathrm{CC}$ to $3 \mathrm{R}-\mathrm{CC}$ & 4.4 & early Pliocene & Berggren et al., 1985 & 17.3 \\
\hline $\mathrm{F}$ & occ. Morozovella aragonensis & $3 \mathrm{R}-\mathrm{CC}$ & $46.0-55.2$ & early Eocene & Berggren et al., 1985 & $46.0-55.2$ \\
\hline $\mathrm{N}$ & FO Discoaster sublodoensis & $3 R-5,93$, to $3 R-6,113$ & 52.6 & early Eocene & Berggren et al,, 1985 & 24.2 \\
\hline $\mathrm{N}$ & FO Discoaster lodoensis & $4 \mathrm{R}-1,100$, to $4 \mathrm{R}-1,100$ & 55.3 & early Eocene & Berggren et al., 1985 & 28 \\
\hline F & FO Morozovella formosa & $4 \mathrm{R}-\mathrm{CC}$ to $5 \mathrm{R}-\mathrm{CC}$ & 56.1 & early Eocene & Berggren et al., 1985 & 36.7 \\
\hline $\mathrm{N}$ & FO Ericsonia robusta & $5 R-5,44$, to $5 R-6,44$ & 58.6 & late Paleocene & Berggren et al., 1985 & 43.1 \\
\hline N & LO Fasciculithus & $6 \mathrm{R}-\mathrm{CC}$ to $7 \mathrm{R}-1,100$ & 57.6 & late Paleocene & Berggren et al., 1985 & 57 \\
\hline $\mathrm{N}$ & FO Discoaster diastypus & $6 \mathrm{R}-5,100$, to $6 \mathrm{R}-6,114$ & 56.5 & early Eocene & Berggren et al., 1985 & 53.3 \\
\hline $\mathrm{N}$ & FO Discoaster mohleri & $8 \mathrm{R}-\mathrm{CC}$ to $9 \mathrm{R}-1,109$ & 60.4 & late Paleocene & Berggren et al., 1985 & 75.3 \\
\hline $\mathrm{N}$ & FO Chiasmolithus danicus & 9R-5, 109 , to $9 \mathrm{R}-\mathrm{CC}$ & 64.8 & early Paleocene & Berggren et al., 1985 & 82.3 \\
\hline $\mathrm{N}$ & FO Cruciplacolithus tenuis & 9R-CC to $10 \mathrm{R}-1,68$ & 65.9 & early Paleocene & Berggren et al., 1985 & 85 \\
\hline $\mathrm{N}$ & FO Micula prinsii & $10 \mathrm{R}-2,100$, to $10 \mathrm{R}-2,130$ & 68.5 & late Maestrichtian & Perch-Nielsen, 1985 & 87.5 \\
\hline $\mathrm{N}$ & FO Micula murus & $10 \mathrm{R}-3,50$, to $10 \mathrm{R}-\mathrm{CC}$ & 70 & Maestrichtian & Perch-Nielsen, 1985 & 88.5 \\
\hline $\mathrm{N}$ & LO Reinhardiites levis & $10 \mathrm{R}-3,50$, to $10 \mathrm{R}-\mathrm{CC}$ & 71 & Maestrichtian & Sissingh, 1977 & 94.7 \\
\hline $\mathrm{N}$ & LO Broinsinia parca constricta & $10 \mathrm{R}-3,50$, to $10 \mathrm{R}-\mathrm{CC}$ & 71 & Maestrichtian & Perch-Nielsen, 1985 & 94.7 \\
\hline F & FO Globotruncanella havanensis & $11 \mathrm{R}-\mathrm{CC}$ to $12 \mathrm{R}-\mathrm{CC}$ & 74 & Maestrichtian & Perch-Nielsen, 1985 & 104.3 \\
\hline $\mathrm{N}$ & FO Reinhardiites levis & $12 \mathrm{R}-\mathrm{CC}$ to $13 \mathrm{R}-1,75$ & 76.5 & Campanian & Perch-Nielsen, 1985 & 113.9 \\
\hline $\mathrm{F}$ & FO Globotruncana ventricosa & $12 \mathrm{R}-\mathrm{CC}$ to $13 \mathrm{R}-\mathrm{CC}$ & 81 & Campanian & Caron, 1985 & 123.6 \\
\hline $\mathrm{N}$ & LO Marthasterites furcatus & $13 \mathrm{R}-1,75$, to $13 \mathrm{R}-2,114$ & 82 & early Campanian & Sissingh, 1977 & 116.5 \\
\hline $\mathrm{N}$ & FO Broinsinia parca constricta & $13 \mathrm{R}-1,75$, to $13 \mathrm{R}-2,114$ & 83 & early Campanian & Perch-Nielsen, 1985 & 114.6 \\
\hline $\mathrm{N}$ & LO Lithastrinus septenarius & $13 \mathrm{R}-2,114$, to $13 \mathrm{R}-3,70$ & 85.5 & Santonian & Perch-Nielsen, 1985 & 117.6 \\
\hline F & LO Dicarinella imbricatalhagni & $13 \mathrm{R}-\mathrm{CC}$ to $14 \mathrm{R}-\mathrm{CC}$ & 86.5 & Coniacian & Caron, 1985 & 133.2 \\
\hline $\mathrm{N}$ & FO Micula decussata & $14 \mathrm{R}-1,14$, to $14 \mathrm{R}-1,48$ & 87.5 & Coniacian & Sissingh, 1977 & 123.7 \\
\hline $\mathrm{N}$ & FO Lithastrinus septenarius & $14 \mathrm{R}-1,48$, to $14 \mathrm{R}-2$ & 89 & late Turonian & Perch-Nielsen, 1985 & 124 \\
\hline $\mathrm{N}$ & FO Marthasterites furcatus & $14 \mathrm{R}-3,35$, to $14 \mathrm{R}-4$ & 89 & late Turonian & Sissingh, 1977 & 126.9 \\
\hline $\mathrm{F}$ & occ. Rotalipora cushmani Zone & 14R-CC & $91-93$ & late Cenomanian & Caron, 1985 & \\
\hline $\mathrm{N}$ & FO Quadrum gartneri & $15 \mathrm{R}-1,100$, to $15 \mathrm{R}-1,100$ & 91 & late Cenomanian & Perch-Nielsen, 1985 & 134.2 \\
\hline $\mathrm{N}$ & LO Corollithon kennedyi & $15 \mathrm{R}-1,100$, to $15 \mathrm{R}-1,100$ & 91 & late Cenomanian & Perch-Nielsen, 1985 & 134.2 \\
\hline $\mathrm{N}$ & FO C. kennedyi & $16 \mathrm{R}-\mathrm{CC}$ to $17 \mathrm{R}-\mathrm{CC}$ & 96 & early Cenomanian & Perch-Nielsen, 1985 & 152.5 \\
\hline $\mathrm{N}$ & FO Eiffellithus turriseiffelii & $16 \mathrm{R}-\mathrm{CC}$ to $17 \mathrm{R}-\mathrm{CC}$ & 100 & late Albian & Sissingh, 1977 & 152.5 \\
\hline $\mathrm{N}$ & LO Rucinolithus irregularis & $17 \mathrm{R}-\mathrm{CC}$ to $18 \mathrm{R}-\mathrm{CC}$ & 102 & Albian & Perch-Nielsen, 1985 & 171.7 \\
\hline $\mathrm{N}$ & FO Praediscosphaera columnata & 20R-CC to 21R-CC & 111 & early Albian & Sissingh, 1977 & 191 \\
\hline $\mathrm{N}$ & FO Hayesites albiensis & $22 \mathrm{R}-\mathrm{CC}$ to $23 \mathrm{R}-\mathrm{CC}$ & 114.5 & late Aptian & Mutterlose, this vol. & 210.3 \\
\hline R & LO Alievum helenae & 23R-CC to 24R-CC & 120 & latest Barremian & Schaaf, 1981 & 229.6 \\
\hline $\mathrm{N}$ & FO Flabellites biforaminis & $27 \mathrm{R}-1,108$, to $27 \mathrm{R}-3,18$ & 118 & early Aptian & Mutterlose, this vol. & 249.9 \\
\hline$R$ & FO Sethocapsa euganea & $24 \mathrm{R}-\mathrm{CC}$ to $25 \mathrm{R}-\mathrm{CC}$ & 119 & Barremian/Aptian & Shaaf, 1985 & 229.6 \\
\hline R & LO Pseudodictyomitra lilyae & $24 \mathrm{R}-\mathrm{CC}$ to $25 \mathrm{R}-\mathrm{CC}$ & 120 & late Barremian & Schaaf, 1981 & 239.9 \\
\hline $\mathrm{N}$ & FO Rhagodiscus angustus & $26 \mathrm{R}-1,10$, to $26 \mathrm{R}-2,141$ & 116 & Barremian/Aptian & Thierstein, 1971 & 239.4 \\
\hline N & FO Chiastozygus litteriarius & $26 \mathrm{R}-2,141$, to $27 \mathrm{R}-1,108$ & 118 & base Aptian (Chron M0) & Bralower, 1987 & 242.2 \\
\hline N & FO Rucinolithus irregularis & $28 \mathrm{R}-5,51$, to $28 \mathrm{R}-6,69$ & 118 & base Aptian (Chron M0) & Bralower, 1987 & 265.1 \\
\hline $\mathrm{N}$ & FO Eprolithus apertior & $28 \mathrm{R}-6,69$, to $29 \mathrm{R}-1,119$ & 119 & Barremian/Aptian & Mutterlose, this vol. & 266.6 \\
\hline $\mathrm{N}$ & LO Cruciellipsis cuvillieri & $29 \mathrm{R}-1,119$, to $29 \mathrm{R}-3,40$ & 129 & Hauterivian/Barremian & Bralower, 1987 & 271.7 \\
\hline $\mathbf{N}$ & LO Speetonia colligata & $33 \mathrm{R}-1,95$, to $33 \mathrm{R}-3,33$ & 130 & mid-Hauterivian & Mutterlose, this vol. & 310.1 \\
\hline$P$ & LO Muderongia testudinaria & $36 \mathrm{R}-1,80$, to $36 \mathrm{R}-\mathrm{CC}$ & 128 & early Barremian & Helby et al., 1987 & 345.5 \\
\hline P & FO Dingodinium cerviculum & $38 \mathrm{R}-\mathrm{CC}$ to $40 \mathrm{R}-\mathrm{CC}$ & 130 & Hauterivian & Helby et al., 1987 & 364.8 \\
\hline N & LO Tegumentum tripes & $45 \mathrm{R}-5,97$, to $45 \mathrm{R}-3,148$ & 130 & Hauterivian & Mutterlose, in press & 427.2 \\
\hline P & FO Phoberacysta burgeri & $48 \mathrm{R}-5,3$, to $49 \mathrm{R}-2,138$ & 133 & Valanginian & Helby et al., 1987 & 457.8 \\
\hline $\mathbf{R}$ & occ. Praeconocaryomma prisca & $49 \mathrm{R}-3,92$, to $49-4,23$ & $130-134$ & $\begin{array}{l}\text { late Valanginian- } \\
\text { early Hauterivian }\end{array}$ & Baumgartner, this vol. & $130-134$ \\
\hline
\end{tabular}

foraminifers. Nannofossils display moderate to good preservation, but planktonic foraminiferal assemblages between Core 123$766 \mathrm{~A}-10 \mathrm{R}$ and $-15 \mathrm{R}$ have been affected by severe dissolution.

The highest assemblage with in-situ Cretaceous nannofossils was found in Sample 123-766A-10R-2, $100 \mathrm{~cm}$. Just below this level, Sample 123-766A-10R-2, $130 \mathrm{~cm}$, the association of Nephrolithus frequens, together with $B$. sparsus, $P$. sigmoides, Thoracosphaera sp., and $M$. inversus indicates the uppermost Maestrichtian Zone CC26 ( $N$. frequens). Sample 123-766A-10R-3, $1 \mathrm{~cm}$, was placed in Zone CC25 (Arkhangelskiella cymbiformis), as indicated by the presence of Micula murus.

The Campanian is present in the interval from Samples 123$766 \mathrm{~A}-10 \mathrm{R}-\mathrm{CC}$ to $123-766 \mathrm{~A}-13 \mathrm{R}-2,115 \mathrm{~cm}$. The presence of the planktonic foraminifers Globotruncanella havanensis and Rugo- globigerina milamensis in Sample 123-766A-10R-CC suggests that this level is no lower than uppermost Campanian. Core-catcher samples from Cores $123-766 \mathrm{~A}-10 \mathrm{R}$ to $-12 \mathrm{R}$ contain the nannofossils Aspidolithus parcus constrictus and Reinhardiites levis and belong to Zone CC22b-23a (Quadrum trifidum to Tranolithus phacelosus) of late Campanian age. Sample 123-766A-13R-2, $115 \mathrm{~cm}$, contains an early Campanian assemblage characterized by Marthasterites furcatus and A. parcus parcus, indicating Zone CC18 (A. parcus).

The Santonian is present in Samples 123-766A-13R-3, $70 \mathrm{~cm}$, and 123-766A-13R-CC. These samples contain Lithastrinus septenarius, L. grilli, Reinhardtiites anthrophorus, and Marthasterites furcatus, indicating Zone $\mathrm{CC} 15$ ( $R$. anthrophorus), of late Santonian age. The uppermost Santonian Zone CC16 (L. cayeuxii) 


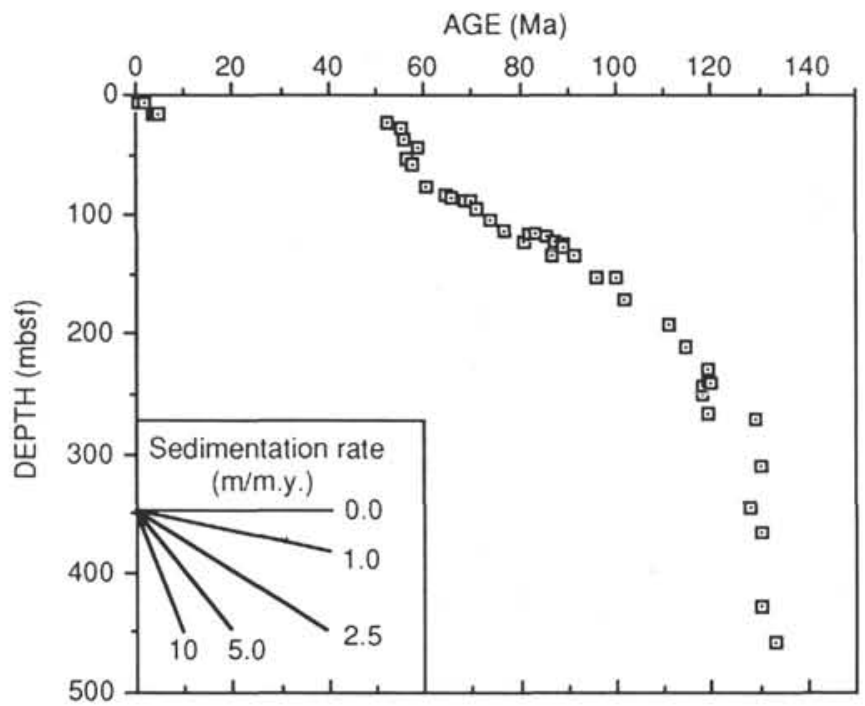

Figure 8. Age-depth curve for Hole 766A, derived from magnetobiostratigraphic data in Table 3.

and lowermost Campanian Zone $\mathrm{CC} 17$ ( $C$. obscurus) were not observed in the samples examined. This may be due to ecological reasons or to diagenetic removal of the marker species.

The Coniacian was observed in Core 123-766A-14R. Sample 123-766A-14R-1, $15 \mathrm{~cm}$, contains $M$. furcatus, $L$. septenarius, $Q$. gartneri, the LO of Eprolithus florialis, and the FO of Micula decussata. Reinhardiites anthophorus is lacking, which indicates Zone CC14 (M. decussata) of late Coniacian/early Santonian age. The absence of $M$. decussata in Sample 123-766A-14R-1, $48 \mathrm{~cm}$, indicates Zone CC13 (M.furcatus), of Coniacian age. All samples from Sections 123-766A-14R-2 and -14R-3 contain $M$. furcatus, $Q$. gartneri, and E. florialis and were assigned to Zone CC13. Beginning with Core 123-766A-14R, all NRM measurements yielded stable normal polarity, which is consistent with deposition during the Cretaceous quiet zone.

The Turonian is represented in Sections 123-766A-14R-3 to $-15 \mathrm{R}-1$. The upper Turonian Zone CC12 (L. maleformis) was observed in Sample 123-766A-14R-3, 23-25 cm. Samples from Sections 123-766A-14R-4, and -14R-CC contain $Q$. gartneri, but lack $M$. furcatus, Eiffellithus eximus, and Lucianorhabdus maleformis, which indicates Zone CC11 (Q. gartneri). Sample 123766A-14R-CC contains an abundant, though poorly preserved, Turonian planktonic foraminiferal assemblage that is dominated by the Dicarinella imbricata/hagni Group, along with Praeglobotruncana stephani and $P$. gibba.

The Cenomanian/Turonian boundary lies between Sample 123-766A-15R-1, $100 \mathrm{~cm}$, which contains the FO of $Q$. gartneri, and Sample 123-766A-15R-3, $100 \mathrm{~cm}$, which contains the LO of Corollithion kennedyi, marking the top of Zone $\mathrm{CC} 10(M$. decoratus). Sample 123-766A-15R-CC contains an upper Cenomanian planktonic foraminiferal assemblage with Rotalipora greenhornensis, Praeglobotruncana delrioensis, P. stephani, and Whiteinella brittonensis and belongs to the Rotalipora cushmani Zone of Caron (1985).

\section{Lower Cretaceous}

The chronostratigraphy of Lower Cretaceous sediments is based upon calcareous nannofossils and planktonic foraminifers in the Albian to Cenomanian and on palynomorphs, radiolarians, benthic foraminifers, and magnetostratigraphy in the Neocomian. The placement of chronostratigraphic boundaries was constrained by the magnetostratigraphic pattern. There is apparent conflict between nannofossil biostratigraphy, which suggests an extremely condensed or missing Barremian (Mutterlose, this volume), and radiolarians, palynomorphs, and magnetics, which suggest a relatively thick Barremian.

The Albian/Cenomanian boundary is located between Samples 123-766A-15R-CC and -16R-3, 46-50 cm. The FO of Eiffellithus turriseiffelii in Sample 123-766A-17R-4, 80-82 cm, characterizes the boundary between Zone CC8 (Praediscosphaera columnata) and the overlying Zone CC9 (E. turriseiffelii). The planktonic foraminiferal assemblages provide useful information for the uppermost Albian interval (Haig, this volume). Samples 123$766 \mathrm{~A}-16 \mathrm{R}-3,46-50 \mathrm{~cm}$, through $-16 \mathrm{R}-\mathrm{CC}$ lie within the range of Planomalina buxtorfi and belong to the undifferentiated Pseudothalmanninella tincinensis-Planomalina buxtorfi and Thalmanninella appenninica-Planomalina buxtorfi Zones (uppermost Albian) of Wonders (1980). The presence of advanced $R$. appenninica grading into $R$. globotruncanoides suggests that Sample 123$766 \mathrm{~A}-16 \mathrm{R}-3,46-50 \mathrm{~cm}$ is close to the Albian/Cenomanian boundary. Samples 123-766A-17R-2, 125-128 cm, and -17R-3, 36-39 correlate with the Planomalina praebuxtorfi Subzone of Leckie (1984), of late Albian age. Below this level, correlations based on planktonic foraminifers are tentative because of the absence of commonly used zonal index species. The development of Hedbergella assemblages in the interval ranging from Core 123766A-17R downward to Core $123-766 \mathrm{~A}-21 \mathrm{R}$, is broadly similar to those recorded in the Australian "Great Artesian Basin" by Playford et al. (1975) and Haig (1979). The upper Albian interval (down to approximately Core $123-766 \mathrm{~A}-18 \mathrm{R}-3$ ) contains abundant Hedbergella cf. punctata and Hedbergella vezoana. Sections 123-766A-18R-5 through -21-CC, contain abundant Hedbergella planispira and were assigned to the lower and middle Albian. The interval between Samples 123-766A-17R-CC and -22R-CC contains an Albian nannofossil assemblage that was assigned to Zone CC8 ( $P$. columnata), based on the presence of Chiastozygus litterarius, Eprolithus apertior, E. floralis, P. columnata, Flabellites biforaminis, Stoverius achylosus, and Hayesites irregularis. The FO of $P$. columnata in Sample 123-766A-22R-CC marks the base of this zone. The occurrence of Hedbergella trochoidea together with Favusella sp. in Sample 123-766A-21R-CC suggests this level is near the Aptian/Albian boundary.

The Aptian/Albian boundary probably occurs within Core 123-766A-23R, which had poor recovery. The interval between Samples $123-766 \mathrm{~A}-23 \mathrm{R}-1,30 \mathrm{~cm}$, to $-26 \mathrm{R}-1,10 \mathrm{~cm}$, contains nannofossil assemblages with Rhagodiscus angustus and Flabellites biforaminis and belongs to the lower Aptian Zone CC7A. However, the first occurrence of abundant Hedbergella cf. planispira in Sample 123-766A-25R-1, 33-35 cm, and the presence of Globigerinelloides aptiensis in Sample 123-766A-25R-CC suggest a correlation with the upper Aptian (Haig, this volume). Radiolarian assemblages between Samples 123-766A-22R-CC and $-24 \mathrm{R}-\mathrm{CC}$ were assigned to the lower Sethocapsa euganea Zone of Schaaf (1985), which is of Aptian age. The LO of the radiolarian Alievum helenae, co-occurring with rare Sethocapsa euganea in Sample 123-766A-24R-CC, suggests that this level is near the Barremian/Aptian boundary.

Nannofossils of definite Barremian age were found in Sample $123-766 \mathrm{~A}-28 \mathrm{R}-5,51-52 \mathrm{~cm}$. This sample contains the FO of Hayesites irregularis. Other species typical for the Aptian include $E$. varolii in Sample 123-766A-28R-4, $62-63 \mathrm{~cm}$, and $F$. biforaminis in Sample 123-766A-27R-1, 108-109 cm. Palynomorphs belonging to the Barremian upper Muderongia australis Zone of Helby et al. (1987) were found in Samples 123-766A-28R-CC to $123-766 \mathrm{~A}-32 \mathrm{R}-\mathrm{CC}$. The long reversed-polarity zone that extends through Cores $123-766 \mathrm{~A}-28 \mathrm{R}$ and $-29 \mathrm{R}$ is probably Chron M3r. Adjacent polarity Chron M1r may be the reversed-polarity zone in Core 123-766A-27R, which had poor recovery. However, there 


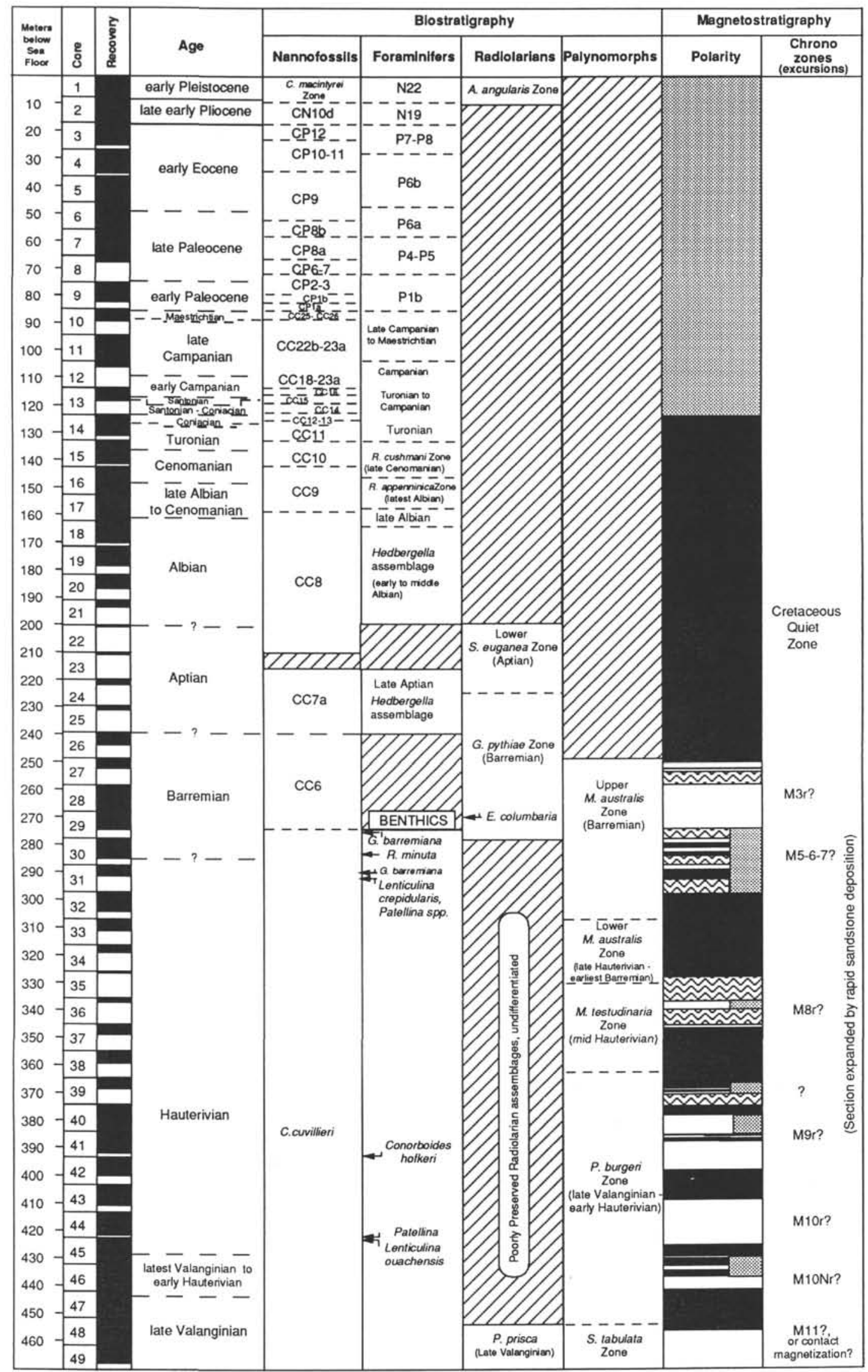

Figure 9. Magnetobiostratigraphic synthesis and chronostratigraphy of Hole 766A. 
is no indication of reversed-polarity Zone M0r at the top of the claystone unit in Core 123-766A-26R or in the overlying Aptian white limestone. The facies change probably corresponds to a hiatus that incorporates the uppermost Barremian to lowermost Aptian.

The Hauterivian/Barremian boundary is located within the interval between Core 123-766A-29R and -33R, based on somewhat conflicting paleontologic data. The LO of the nannofossil Cruciellipsis cuvillieri was observed in Sample 123-766A-29R-3, $40-41 \mathrm{~cm}$. If not reworked, the Hauterivian/Barremian boundary may be as high as Core 123-766A-29R. However, palynomorph assemblages provide evidence for the placement of the Hauterivian/Barremian boundary below Core 123-766A-32R. The boundary between the Barremian upper $M$. australis Zone and the upper Hauterivian to lowest Barremian lower Muderongia australis Zone of Helby et al. (1987) was found within Core 123-766A33R. The LO of the benthic foraminifers Marginulopsis collignoni was observed in Sample 123-766A-32R-CC, and the LO of Tristix acutiangulata in Sample 123-766A-33R-CC. Both species display LOs near the Hauterivian/Barremian boundary at Site 416 in the North Atlantic. Nannofossil assemblages in the interval between Samples 123-766A-33R-CC and -44R-CC are well preserved and contain Crucibiscutum salebrosum and Micrantholithus hoschulzii, in addition to $C$. cuviellieri, which indicates a Hauterivian age. Palynomorph assemblages can be used to subdivide the Hauterivian into upper, middle, and lower intervals. Core-catcher samples from Cores $123-766 \mathrm{~A}-33 \mathrm{R}$ to $-35 \mathrm{R}$ include the species Cribroperidinium sp., Circulodinium deflandrei, Leptodinium spp., Circulodinium deflandrei, and Leptodinium spp. and were assigned to the lower Muderongia australis Zone. Samples 123-766A-36R-1, 79-80 cm; 123-766A-36R-CC; and 123$766 \mathrm{~A}-37 \mathrm{R}-2,5-7 \mathrm{~cm}$, contain assemblages of the middle Hauterivian Muderongia testudinaria Zone. Core-catcher samples from Cores $123-766 \mathrm{~A}-40 \mathrm{R}$ to $-47 \mathrm{R}$ contain assemblages equivalent to the Phoberacysta burgeri Zone, of late Valanginian to early Hauterivian age.

The Valanginian/Hauterivian boundary is probably located within Core $123-766 \mathrm{~A}-45 \mathrm{R}$ or $-46 \mathrm{R}$. This interval contains a relatively rich nannofossil assemblage characterized by Tegumentum spp. A similar Tegumentum assemblage, with common $S$. salebrosum, has been described from the uppermost Valanginian to lower Hauterivian of northwest Germany. Mutterlose (this volume) places the Valanginian/Hauterivian boundary within Core 123-766A-45R, based on the LO of Tegumentum striatum. The magnetic polarity-reversal pattern at the base of Hole $766 \mathrm{~A}$ is nearly identical to polarity Chrons M10r to M10Nr, including the two brief reversed-polarity intervals during normal-polarity Chron M10Nn. Reversed-polarity Chron M10Nr, observed in Core 766A-46R, is located at the Valanginian/Hauterivian boundary as recognized in the North Atlantic (Ogg and Steiner, 1988). Palynomorph assemblages belonging to the upper Valanginian Senoniasphaera tabulata Zone were observed in Samples 123$766 \mathrm{~A}-48 \mathrm{R}-5,0-3 \mathrm{~cm}$, and $-49 \mathrm{R}-2,138-140 \mathrm{~cm}$. Two samples from Core 123-766A-49R, from sediment layers between basalt sills, yield a moderately preserved radiolarian assemblage that includes Eucyrtis micropora, Praeconocaryomma prisca, Praeconocaryomma spp., and Parvicingula spp. These assemblages are similar to those recovered at Site 765 in Cores $123-765 \mathrm{C}-57 \mathrm{R}$ to $-59 \mathrm{R}$ and have been dated as late Valanginian, based on the presence of $P$. prisca. The lowermost nannofossil assemblage, in Sample 123-766A-50R-1, $5 \mathrm{~cm}$, contains $W$. barnesae, $C$. cuvillieri, $C$. salebrosum, T. tripes, and Tegumentum striatum. The presence of $T$. tripes and $T$. striatum indicates a late Valanginian age.

\section{ACKNOWLEDGMENTS}

The Leg 123 paleontologists are grateful to the Ocean Drilling Program for the opportunity to participate in Leg 123 and to the captain, crew, and technical staff of the JOIDES Resolution for providing samples and logistic support. M.A.K. gratefully acknowledges travel support from an NSERC Strategic Grant to Ron Boyd (Dalhousie University). P.O.B. thanks the Swiss National Science Foundation for travel support and research funds. Joseph E. Hazel and Scott W. Snyder reviewed an early draft of this manuscript and provided many useful suggestions.

\section{REFERENCES}

Aita, Y., 1987. Middle Jurassic to Lower Cretaceous radiolarian biostratigraphy of Shikoku with reference to selected sections in Lombardy Basin and Sicily. Geology, 58:91-115.

Apthorpe, M. C., 1988. Cainozoic depositional history of the Northwest Shelf. In Purcell, P. G., and Purcell, R. R. (Eds.), The Northwest Shelf, Australia. Proc. Pet. Expl. Soc. Aust. Symp., 55-84.

Aubry, M.-P., Berggren, W. A., Kent, D. V., Flynn, J. J., Klitgord, K. D., Obradovich, J. D., and Prothero, D. R., 1988. Paleogene geochronology: an integrated approach. Paleoceanography, 3:707-742.

Audley-Charles, M. G., Ballantyne, P. D., and Hall, R., 1988. MesozoicCenozoic rift-drift sequence of Asian fragments from Gondwanaland. Tectonophysics, 155:317-330.

Banner, F. T., and Blow, W. H., 1965. Progress in the planktonic foraminiferal biostratirgaphy of the Neocene. Nature, 209:1164-1166.

Bartenstein, H., 1974. Upper Jurassic-Lower Cretaceous primitive arenaceous foraminifers from DSDP Sites 259, and 261, eastern Indian Ocean. In Veevers, J. J., Heirtzler, J. R., et al., Init. Repts. DSDP, 27: Washington (U.S. Govt. Printing Office), 683-695.

Bartenstein, H., and Brand, E., 1951. Mikropalaontologische Untersuchungen zur Stratigraphie des nordwestdeutschen Valendis. Abh. Senckenb. Naturforsch. Ges., 485:239-336.

Baumgartner, P. O., 1984. A Middle Jurassic-Early Cretaceous low-latitude radiolarion zonation based on unitary associations and age of Tethyan radiolarites. Eclogae Geol. Helv., 77:729-837.

1987. Age and genesis of Tethyan Jurassic radiolarites. Eclogae Geol. Helv., 80:831-879.

Belford, D. J., 1981. Late Cretaceous planktonic foraminifera in Valdivia core KL1 from the Scott Plateau and Rowley Terrace, off northwestern Australia. Bull.Bur.Miner. Resour., Geol.Geophys.(Aust.), 213:48-67.

Berggren, W. A., 1969. Cenozoic chronostratigraphy, planktonic foraminiferal zonation, and the radiometric time scale. Nature, 224:10721075.

Berggren, W. A., and Kaminski, M. A., 1990. Abyssal agglutinates: back to basics. In Hemleben, C., Kaminski, M. A., Kuhnt, W., and Scott, D. B. (Eds.), Paleoecology, Biostratigraphy, Paleoceanography and Taxonomy of Agglutinated Foraminifera. NATO ASI Ser., Ser. C, 327:53-75.

Berggren, W. A., Kent, D. V., and Flynn, J. J., 1985a. Jurassic to Paleogene: Part 2. Paleogene geochronology and chronostratigraphy. In Snelling, N. J. (Ed.), The Chronology of the Geological Record. Geol. Soc. London Mem., 10:141-195.

Berggren, W. A., Kent, D. V., and Van Couvering, J. A., 1985b. The Neogene: Part 2. Neogene geochronology and chronostratigraphy. In Snelling, N. J. (Ed.), The Chronology of the Geological Record. Geol. Soc. London Mem., 10:211-260.

Blow, W. H., 1969. Late middle Eocene to Recent planktonic foraminiferal biostratigraphy. In Brönniman, P., and Renz, H. H. (Eds.), Proc. First Int. Conf. Planktonic Microfossils, Geneva, 1967. Leiden (E. J. Brill), 1:199-422.

1979. The Cainozoic Globigerinida: Leiden (E. J. Brill).

Bown, P. R., Cooper, M.K.E., and Lord, A. R., 1988. A calcareous nannofossil biozonation scheme for the early to mid Mesozoic. Newsl. Stratigr., 20:91-114.

Bralower, T. J., 1987. Valanginian to Aptian calcareous nannofossil stratigraphy and correlation with the upper M-sequence magnetic anomalies. Mar. Micropaleontol., 11:293-310.

Bukry, D., 1981. Pacific coast coccolith stratigraphy between Point Conception and Cabo Corientes, Deep Sea Drilling Project, Leg 63. In Yeats, R. S., Haq, B. U., et al., Init. Repts. DSDP, 63: Washington (U.S. Govt. Printing Office), 445-471.

Caron, M., 1985. Cretaceous planktic foraminifera. In Bolli, H. M., Saunders, J. B., and Perch-Nielsen, K. (Eds.), Plankton Stratigraphy: Cambridge (Cambridge Univ. Press), 17-86. 
Casey, R. E., and Reynolds, R. A., 1980. Late Neogene radiolarian biostratigraphy and paleoceanography with suggested cosmopolitan radiolarian datums. Spec. Publ. Cushman Found. Foraminiferal Res., 19:287-300.

Channell, J.E.T., Lowrie, W., and Midizza, R., 1979. Middle and Early Cretaceous magnetic stratigraphy from the Cismon section, Northern Italy. Earth Planet. Sci. Lett., 42:153-166.

Chaproniere, G.C.H., 1981. Late Oligocene to early Miocene planktonic foraminifers from Ashmore Reef No. 1 well, northwest Australia. Alcheringa, 5:103-131.

Cooper, M.K.E., 1984. Nannofossils across the Jurassic/Cretaceous boundary in the Tethyan Realm. Int. Symp. Jurassic Stratigr., 2:429_ 443.

Dailey, D. H., 1983. Late Cretaceous and Paleocene benthic foraminifers from Deep Sea Drilling Project Site 516, Rio Grande Rise, western South Atlantic Ocean. In Barker, P. F., Carlson, R. L., et al., Init Repts. DSDP, 72: Washington (U.S. Govt. Printing Office), 757-782.

Fullerton, L. G., Sager, W. W., and Handschumacher, D. W., 1989. Late Jurassic-Early Cretaceous evolution of the eastern Indian Ocean adjacent to Northwest Australia. J. Geophys. Res., 94:2937-2953.

Gartner, S., 1977. Calcareous nannofossil biostratigraphy and revised zonation of the Pleistocene. Mar. Micropaleontol., 2:1-25.

Geroch, S., and Nowak, W., 1984. Proposal of zonation for the late Tithonian-Late Eocene, based upon arenaceous foraminifera from the Outer Carpathians, Poland. In Oertli, H. J. (Ed.), Benthos '83: 2nd Int. Symp. on Benthic Foraminifera (Pau, April 1983), 225-239.

Gradstein, F. M., 1978. Biostratigraphy of Lower Cretaceous Blake Nose and Blake Bahama Basin foraminifera, DSDP Leg 44, western North Atlantic Ocean. In Benson, W. E., Sheridan, R. E., et al., Init. Repts. DSDP, 44: Washington (U.S. Govt. Printing Office), 663-702.

1983. Paleoecology and stratigraphy of Jurassic abyssal foraminifera in the Blake-Bahama Basin, Deep Sea Drilling Project Leg 76, Sites 533 and 534. In Sheridan, R. E., Gradstein, F. M., et al., Init. Repts. DSDP, 76: Washington (U.S. Govt. Printing Office), 537-560.

1986. Northwestern Atlantic Mesozoic biostratigraphy. In Vogt, P. R., et al. (Eds.), The Geology of North America (Vol. M): The Western North Atlantic Region. Geol. Soc. Am., 507-525.

Haig, D. W., 1979. Cretaceous foraminiferal biostratigraphy of Queensland. Alcheringa, 3:171-187.

1981. Mid-Cretaceous foraminiferids from the Wahgi Valley, Central Highlands of Papua New Guinea. Micropaleontology, 27:337-351.

Hansen, J. M., 1977. Dinoflagellate stratigraphy and echinoid distribution in Upper Maastrichtian and Danian deposits from Denmark. Bull. Geol. Soc. Den., 26:1-26.

Haq, B. U., Hardenbol, J., and Vail, P. R., 1987. Chronology of fluctuating sea levels since the Triassic. Science, 235:1156-1167.

Helby, R., Morgan, R., and Partridge, A. D., 1987. A palynological zonation of the Australian Mesozoic. In Jell, P. A. (Ed.), Studies in Australian Mesozoic Palynology. Mem. Assoc. Australas. Palaeontol., 4:1-94.

Hemleben, C., and Troester, J., 1984. Campanian-Maestrichtian deepwater foraminifers from Hole 534A, Deep Sea Drilling Project. In Biju-Duval, B., Moore, J. C., et al., Init. Repts. DSDP, 78A: Washington (U.S. Govt. Printing Office), 509-532.

Herb, R., and Scheibnerova, V., 1977. Synopsis of Cretaceous planktonic foraminifera from the Indian Ocean. In Heirtzler, J. R., Bolli, H. M., et al. (Eds.), Indian Ocean Geology and Biostratigraphy. Am. Geophys. Union, 399-415.

Kennett, J. P., and Srinivasan, M. S., 1983. Neogene Planktonic Foraminifera: A Phylogenetic Atlas: Stroudsburg, PA (Hutchinson Ross).

Kent, D. V., and Gradstein, F. M., 1986. A Jurassic to Recent chronology. In Vogt, P. R., and Tucholke, B. E. (Eds.), The Geology of North America (Vol. M): The Western North Atlantic Region: Geol. Soc. Am., 45-50.

Krasheninnikov, V. A., 1974. Upper Cretaceous benthonic agglutinated foraminifera, Leg 27 of the Deep Sea Drilling Project. In Veevers, J. J., Heirtzler, J. R., et al., Init. Repts. DSDP, 27: Washington (U.S. Govt. Printing Office), 631-661.

Kuhnt, W., and Kaminski, M., 1989. Upper Cretaceous deep-water agglutinated benthic foraminiferal assemblages from the Western Mediterranean and adjacent areas. In Wiedmann, J. (Ed.), Cretaceous of the Western Tethys. Proc. 3rd Inter. Cretaceous Symp., Tübingen.
Kuznetsova, K. I., 1974. Distribution of benthonic foraminifera in Upper Jurassic and Lower Cretaceous deposits at Site 261, DSDP Leg 27, in the eastern Indian Ocean. In Veevers, J. J., Heirtzler, J. R., et al., Init. Repts. DSDP, 27: Washington (U.S. Govt. Printing Office), 673-681.

Kuznetsova, K. I., and Seibold, I., 1978. Foraminifers from the Upper Jurassic and Lower Cretaceous of the Eastern Atlantic (DSDP Leg 41, Sites 367 and 370). In Lancelot, Y., Seibold, E., et al., Init. Repts. DSDP, 41: Washington (U.S. Govt. Printing Office), 515-538.

Leckie, R. M., 1984. Mid-Cretaceous planktonic foraminiferal biostratigraphy off Central Morocco, Deep Sea Drilling Project Leg 79, Sites 545 and 547. In Hinz, K., Winterer, E. L., et al., Init. Repts. DSDP, 79: Washington (U.S. Govt. Printing Office), 579-620.

Luterbacher, H., 1972. Foraminifera from the Lower Cretaceous and Upper Jurassic of the northwestern Atlantic. In Hollister, C. D., Ewing, J. I., et al., Init. Repts. DSDP, 11: Washington (U.S. Govt. Printing Office), 561-594.

Martini, E., 1971. Standard Tertiary and Quaternary calcareous nannoplankton zonation. In Farinacci, A. (Ed.), Proc. 2nd Planktonic Conf. Roma: Rome (Ed. Technosci.), 2:739-785.

Maync, W., 1973. Lower Cretaceous foraminiferal fauna from Gorringe Bank, eastern North Atlantic. In Ryan, W.B.F., Hsü, K. J., et al., Init. Repts DSDP, 13: Washington (U.S. Govt. Printing Office), 1075-1111.

McGowran, B., 1977. Maastrichtian to Eocene foraminiferal assemblages in the northern and eastern Indian Ocean region: correlations and historical patterns. In Heirtzler, J. R., Bolli, H. M., Davies, T. A., Saunders, J. B., and Sclater, J. C. (Eds.), Indian Ocean Geology and Biostratigraphy: Washington (Am. Geophys. Union), 417-458.

McMinn, A., 1988a. The Cretaceous-Tertiary boundary in the Bonaparte Basin, northwest Australia. Proc. 7th Int. Palynol. Congr., Brisbane. (Abstract)

, 1988b. Outline of a Late Cretaceous dinoflagellate zonation of northwestern Australia. Alcheringa, 12:137-156.

Moullade, M., 1984. Intérêt des petits foraminifères benthiques "profonds" pour la biostratigraphie et l'analyse des paléoenvironnements océaniques Mésozoïques. In Oertli, H. J. (Ed.), Proc. 2nd Int. Symp. Benthic Foraminifera, (Pau, April 1983), 429-464.

Moullade, M., Kuhnt, W., and Thurow, J., 1988. Agglutinated benthic foraminfers from Upper Cretaceous vareigated clays of the North Atlantic Ocean (DSDP Leg 93 and ODP Leg 103). In Boillot, G., Winterer, E. L., et al., Proc. ODP, Sci. Results, 103: College Station, TX (Ocean Drilling Program), 349-377.

Mutterlose, J., in press. Das Verteilungs- und Migrationsmuster des kalkigen Nannoplanktons in der borealen Unterkreide (Valangin.Apt.) NW-Deutschlands. Palaeontographica $B$.

Ogg, J. G., 1984. Comment on "Magnetostratigraphy of the Jurassic-Cretaceous boundary in the Maiolica limestone (Umbria Italy)." Geology, 12:701-702.

Ogg, J. G., and Lowrie, W., 1986. Magnetostratigraphy of the Jurassic/Cretaceous boundary. Geology, 14:547-550.

Ogg, J. G., and Steiner, M. B., 1988. Late Jurassic and Early Cretaceous magnetic polarity time scale. In Rocha, R. (Ed.), 2nd Int. Symp. Jurassic Stratigr., Lisbon, Sept. 1987: 1125-1138.

Okada, H., and Bukry, D., 1980. Supplementary modification and introduction of code numbers to the low-latitude coccolith biostratigraphic zonation (Bukry, 1973; 1975). Mar. Micropaleontol., 5:321-325.

Perch-Nielsen, K., 1985. Cenozoic calcareous nannofossils. In Bolli, H. M., Saunders, J. B., and Perch-Nielsen, K. (Eds.), Plankton Stratigraphy: Cambridge (Cambridge Univ. Press), 427-554.

Pessagno, E. A., 1977. Lower Cretaceous radiolarian biostratigraphy of the Great Valley sequence and Franciscan complex, California coast ranges. Spec. Publ. Cushman Found. Foraminiferal Res., 15:1-87.

Proto Decima, F., 1974. Leg 27 calcareous nannoplankton. In Veevers, J. J., Heirtzler, J. R., et al., Init. Repts. DSDP, 27: Washington (U.S. Govt. Printing Office), 589-621.

Riedel, W. R., and Sanfilippo, A., 1978. Stratigraphy and evolution of tropical Cenozoic radiolarians. Micropaleontology, 23:61-96.

Riegraf, W., and Luterbacher, H., 1989. Benthonische Foraminiferen aus der Unterkreide des "Deep Sea Drilling Project" (Leg 1-79). Geol. Rundsch., 78:1063-1120.

Rodi, P. H., 1978. Cretaceous nannoplankton biostratigraphy and oceanography of the northwestern Atlantic Ocean. In Benson, W. E., Sheridan, R. E., et al., Init. Repts. DSDP, 44: Washington (U.S. Govt. Printing Office), 731-759. 
Rodi, P. H., Medd, A. W., and Watkins, D. K., 1983. Jurassic calcareous nannofossil zonation, an overview with new evidence from Deep Sea Drilling Project Site 534. In Sheriden, R. E., Gradstein, F. M., et al., Init. Repts. DSDP, 76: Washington (U.S. Govt. Printing Office), 573-579.

Ruddiman, W., Sarnthein, M., Baldauf, J., et al., 1988. Proc. ODP, Init. Repts., 108: College Station, TX (Ocean Drilling Program).

Sanfilippo, A., and Riedel, W. R., 1985. Cretaceous radiolaria. In Bolli, H. M., Saunders, J. B., and Perch-Nielsen, K. (Eds.), Plankton Stratigraphy: Cambridge (Cambridge Univ. Press), 573-630.

Sanfilippo, A., Westberg-Smith, M. J., and Riedel, W. R., 1985. Cenozoic radiolaria. In Bolli, H. M., Saunders, J. B., and Perch-Nielsen, K. (Eds.), Plankton Stratigraphy: Cambridge (Cambridge Univ. Press), 631-712.

Schaaf, A., 1981. Late Cretaceous radiolarians from Deep Sea Drilling Project Leg 62. In Thiede, J., Vallier, T. L., et al., Init. Repts. DSDP. 62: Washington (U.S. Govt. Printing Office), 419-470.

1985. Un nouveau canevas biochronologique du Crétace Inférieur et moyen: les biozones radiolares. Sci. Geol. Bull., 38:227269.

Shipboard Scientific Party, 1990. Explanatory notes. In Haq, B. U., von Rad, U., et al., Proc. ODP. Init. Repts., 122: College Station, TX (Ocean Drilling Program), 17-38.

, 1990. Site 765. In Ludden, J. N., Gradstein, F. M., et al., Proc $O D P$, Init. Repts., 123: College Station, TX (Ocean Drilling Program), 63-267.

Sissingh, W., 1977. Biostratigraphy of Cretaceous calcareous nannoplankton. Geol. Mijnbouw, 56:37-65.

Sliter, W. V., 1980. Mesozoic foraminifers and deep-sea benthic environments from Deep Sea Drilling Project Sites 415 and 416, eastern north Atlantic. In Lancelot, Y., Winterer, E. L., et al., Init. Repts. DSDP, 50: Washington (U.S. Govt. Printing Office), 353-428.

Stam, B., 1986. Quantitative analysis of Middle and Late Jurassic foraminifera from Portugal and its implications for the Grand Banks of Newfoundland. Utrecht Micropaleontol. Bull., 34:1-167.

Thierstein, H. R., 1971. Tentative Lower Cretaceous nannoplankton zonation. Eclogae Geol. Helv., 64:458-488.
1976. Mesozoic calcareous nannoplankton biostratigraphy of marine sediments. Mar. Micropaleontol., 1:325-362.

Tjalsma, R. C., and Lohmann, G. P., 1983. Paleocene-Eocene bathyal and abyssal benthic foraminifera from the Atlantic Ocean. Micropaleontol. Spec. Publ., 4:1-90.

Vandenberg, J., and Wonders, A.A.H., 1980. Paleomagnetism of Late Mesozoic pelagic limestones from the Southern Alps. J. Geophys. Res., 85:3623-3627.

van Morkhoven, F.P.C.M., Berggren, W. A., and Edwards, A. S., et al., 1986. Cenozoic cosmopolitan deep-water benthic foraminifera. Bull. Cent. Rech. Explor.-Prod. Elf-Aquitaine, Mem. 11.

Vincent, E., 1977. Indian Ocean Neogene planktonic foraminiferal biostratigraphy and its paleoceanographic implications. In Heirtzler, J. R., Bolli, H. M., Davies, T. A., Saunders, J. B., and Sclater, J. G. (Eds.), Indian Ocean Geology and Biostratigraphy. Am. Geophys. Union, 469-584.

von Rad, U., Thurow, J., Haq, B. U., Gradstein, F., Ludden, J., and ODP Leg 122/123 Shipboard Scientific Parties, 1989. Triassic to Cenozoic evolution of the NW Australian continental margin and the birth of the Indian Ocean (preliminary results of ODP Legs 122 and 123). Geol. Rundsch., 78:1189-1210.

Williams, G. L., 1977. Dinocysts: their palaeontology, biostratigraphy and palaeoecology. In Ramsey, A.T.S. (Ed.), Oceanic Micropalaeontology: London (Academic Press), 1231-1325.

Wright, C. A., and Apthorpe, M., 1977. Planktonic foraminiferids from the Maastrichtian of the Northwest Shelf, Western Australia. J. Foraminiferal Res., 7:668-641.

Zijderveld, J.D.A., Zachariasses, J. W., Verhallen, P.J.J.M., and Hilgen, F. J., 1986. The age of the Miocene-Pliocene boundary. Newsl. Stratigr., 16:169-181.

Date of initial receipt: 10 September 1990

Date of acceptance: 13 February 1991

Ms 123B-115 